\title{
Seaweed Secondary Metabolites In Vitro and In Vivo Anticancer Activity
}

\author{
Djenisa H. A. Rocha ${ }^{1}\left(\mathbb{D}\right.$, Ana M. L. Seca ${ }^{1,2}$ (1) and Diana C. G. A. Pinto ${ }^{1, *(1)}$ \\ 1 Department of Chemistry \& QOPNA-Organic Chemistry, Natural Products and Food Stuffs, \\ University of Aveiro, Campus de Santiago, 3810-193 Aveiro, Portugal; djenisa@ua.pt (D.H.A.R.); \\ ana.ml.seca@uac.pt (A.M.L.S.) \\ 2 cE3c-Centre for Ecology, Evolution and Environmental Changes, Azorean Biodiversity Group \& Faculty of \\ Sciences and Technology, University of Azores, Rua Mãe de Deus, 9501-321 Ponta Delgada, Portugal \\ * Correspondence: diana@ua.pt; Tel.: +351-234-401-407
}

Received: 14 October 2018; Accepted: 23 October 2018; Published: 26 October 2018

check for updates

\begin{abstract}
Isolation, finding or discovery of novel anticancer agents is very important for cancer treatment, and seaweeds are one of the largest producers of chemically active metabolites with valuable cytotoxic properties, and therefore can be used as new chemotherapeutic agents or source of inspiration to develop new ones. Identification of the more potent and selective anticancer components isolated from brown, green and red seaweeds, as well as studies of their mode of action is very attractive and constitute a small but relevant progress for pharmacological applications. Several researchers have carried out in vitro and in vivo studies in various cell lines and have disclosed the active metabolites among the terpenoids, including carotenoids, polyphenols and alkaloids that can be found in seaweeds. In this review the type of metabolites and their cytotoxic or antiproliferative effects will be discussed additionally their mode of action, structure-activity relationship and selectivity will also be revealed. The diterpene dictyolactone, the sterol cholest-5-en-3 $\beta, 7 \alpha$-diol and the halogenated monoterpene halomon are among the reported compounds, the ones that present sub-micromolar cytotoxicity. Additionally, one dimeric sesquiterpene of the cyclolaurane-type, three bromophenols and one halogenated monoterpene should be emphasized because they exhibit half maximal inhibitory concentration $\left(\mathrm{IC}_{50}\right)$ values between $1-5 \mu \mathrm{M}$ against several cell lines.
\end{abstract}

Keywords: seaweeds; secondary metabolites; cytotoxic activity; cancer; terpenoids; bromophenols; dictyolactone; cholest-5-en-3 $\beta, 7 \alpha$-diol; halomon; laurebiphenyl

\section{Introduction}

Cancer is one of the deadliest diseases, and its influence on European and USA mortality is $20 \%$ and $14 \%$ respectively [1]. It is estimated that in 2018 the numbers will reach values of 18 million new cases and 10 million deaths [1] and it is expected that, in the near future, this numbers will increase [2]. Lung cancer is the most common, both in terms of incidence and mortality, followed by female breast and colorectal cancers. These types of cancers account, each, for nearly 2 million diagnoses in 2018 [1,3]. The top three more frequent cancers diagnosed in women are the breast, lung and colorectal cancers [3], being the lung cancer responsible for more deaths. Whereas in men lung cancer is also the leading cause of death and the more frequent cancer diagnosed, followed by prostate and colorectal cancers [1].

Although significant advances are being made, fully effective cancer therapy is a far way from being achieved [4-6]. The cancer heterogeneity [7], and the development of resistance to anticancer drugs [8] constitute one of the major problems to be overcome. In fact, the treatment of cancer usually comprises a combination of therapies, in accordance with the characteristics and stage of the tumor, including surgery, radio and/or chemotherapy and most recently immunotherapy [9- 
11]. Thus, currently, the development of drugs for a specific cancer-related target, combined with an effective understanding of the drug relationship with human tumor biology became the key in the effort to cure cancer [12].

One of the main sources of drugs are natural compounds, which have demonstrated considerable potential in the cancer therapy $[13,14]$. In fact, at least one-third of the current top twenty drugs are derived from natural sources, including plants and marine species, and among the 175 small molecules approved to treat cancer, $49 \%$ are either natural compounds or directly derived therefrom [15].

Seaweeds or macroalgae are photosynthetic organisms that play a key role in ocean biodiversity and productivity and comprise green algae (Chlorophyta), brown algae (Phaeophyta) and red algae (Rhodophyta). Furthermore, seaweeds are also a source of unique secondary metabolites that showed very interesting bioactivities [16-20]. Due to its nutritional value, seaweeds have also been used as food in many countries of East Asia (Japan, Korea, and China) and in the Celtic cultures of Europe (Ireland, Scotland and Brittany), and used as additive in cosmetic and food industries [21,22].

In the last two decades, seaweed chemical profiles have demonstrated that they are rich in terpenoids, alkaloids, polyphenols, steroids, pigments and polysaccharides and some biological assays showed that several of these metabolites have promising pharmacological activities [23-26] including in cancer therapy [27-29].

This review aims to highlight the secondary metabolites isolated from seaweeds with the highest cytotoxic/antiproliferative activity. Their activity level, chemical structures, putative mechanisms of action will be discussed. Moreover, the reported in vivo studies will be emphasized. It is important to highlight that this is not an exhaustive review but rather an author's selection, where the compounds whose biological activity and mechanism of action suggest that they have significant therapeutic potential. Thus, the discussed and cited studies involve seaweed secondary metabolites exhibiting cytotoxic activities lower than $15 \mu \mathrm{M}$. Exceptions can also be mentioned if they are rare cases or the mechanism of action is elucidated.

\section{Secondary Metabolites from Seaweeds with in Vitro Cytotoxic Activity}

\subsection{Mono-, Sesqui-, Diterpenes and Sterols}

Epidemiological and experimental studies suggest that terpenoids may be helpful to curb the growth of a variety of cancer cells, including mammary, skin, lung, forestomach, colon, pancreatic and prostate carcinomas cells and open more opportunities for cancer therapy [30,31].

The search for anticancer terpenoids from seaweeds in the last 30 years resulted in a significant number of compounds with relevant cytotoxic activity against a large number of cancer cell lines, highlighted on Table 1 and whose chemical structures are presented in Figure 1. 
Table 1. Cytotoxic terpenoids isolated from seaweeds with half maximal inhibitory concentration ( $\mathrm{IC}_{50}$ ) lower than $15 \mu \mathrm{M}$ against tumoral cell lines.

\begin{tabular}{|c|c|c|}
\hline Metabolites & Sources ${ }^{\mathrm{a}}$ [ref.] & Cell Lines Tested $\left(\mathrm{IC}_{50}\right.$ Value $\left.\mu \mathrm{M}\right)$ [ref.] \\
\hline 1 & Cystoseira myrica (S.G.Gmelin) C.Agardh) [32] & KA3IT (13.1); NIH3T3 ${ }^{\text {b }}(19.7)$ [32] \\
\hline 2 & Cystoseira myrica (S.G.Gmelin) C.Agardh [32] & KA3IT (13.7); NIH3T3 b (20.6) [32] \\
\hline 3 & $\begin{array}{l}\text { Cystoseira myrica (S.G.Gmelin) C.Agardh [32]Dictyota dichotoma } \\
\text { (Hudson) I.V.Lamouroux [33] }\end{array}$ & КАЗІТ (14.4); NIH3T3 ${ }^{\mathrm{b}}$ (43.3) [32] \\
\hline 4 & Cystoseira abies-marina (S.G. Gmelin) C. Agardh [34] & HeLa-Log phase (5.6); Vero ${ }^{\text {b}}$-Log phase (14.6) [34] \\
\hline 5 & Dilophus ligulatus (Kützing) Feldmann [35] & P388 (4.33-4.79) [35] \\
\hline 6 & Dilophus ligulatus (Kützing) Feldmann [35] & P388 (11.2); P388/DOX (12.9); NSCLCN6-L16 (6.61) [35] \\
\hline 7 & Dilophus ligulatus (Kützing) Feldmann [35] & P388 (3.64); P388/DOX (5.95); KB (12.2); NSCLCN6-L16 (3.31) [35] \\
\hline 8 & Dilophus ligulatus (Kützing) Feldmann [35] & P388 (7.42); P388/DOX (9.41); KB (14.3), NSCLCN6-L16 (6.85) [35] \\
\hline 9 & Dilophus ligulatus (Kützing) Feldmann [35] & P388 (10.3); P388/DOX (10.8) KB (6.85); NSCLCN6-L16 (1.71) [35] \\
\hline 10 & Dilophus ligulatus (Kützing) Feldmann [35] & P388 (13.3); KB (14.4); NSCLCN6-L16 (4.44) [35] \\
\hline 11 & Dilophus ligulatus (Kützing) Feldmann [35] & P388 (9.26); P388/DOX (7.93) NSCLCN6-L16 (0.99) [35] \\
\hline 12 & Stypopodium zonale (J.V.Lamouroux) Papenfuss [36] & HT-29 (5.83); H-116 (5.83); A549 (5.83) [36] \\
\hline 13 & Stypopodium flabelliforme Weber-van Bosse [37] & NCI-H460 (9) [37] \\
\hline 14 & Stypopodium flabelliforme Weber-van Bosse [37] & NCI-H460 (14) [37] \\
\hline 15 and 16 & Taonia atomaria (Woodward) J. Agardh [38] & NSCLC-N6 (7.35); A549 (7.35) [38] \\
\hline 17 & Stypopodium flabelliforme Weber-van Bosse [39] & SH-SY5Y (12.2) [39] \\
\hline 18 & Stypopodium flabelliforme Weber-van Bosse [39] & SH-SY5Y (14) [39] \\
\hline 19 & $\begin{array}{l}\text { Sargassum fallax Sonder [40]Sargassum yezoense (Yamada) } \\
\text { Yoshida \& T. Konno [41]] }\end{array}$ & P388 (14) [40] \\
\hline 20 & $\begin{array}{l}\text { Laurencia tristicha Tseng, Chang, E.Z. et B.M. Xia [42]Laurencia } \\
\text { nidifica J. Agardh [43] }\end{array}$ & A549 (3.94); HeLa (3.77); BGC-823 (2.86); Bel7402 (4.48); HCT-8 (4.15) [42] \\
\hline 21 & Laurencia tristicha Tseng, Chang, E.Z. et B.M. Xia [44] & HeLa (15.5) [44] \\
\hline 22 & Laurencia tristicha Tseng, Chang, E.Z. et B.M. Xia [44] & HeLa (0.3); BGC-823 (5.1); Bel7402 (0.5); HCT-8 (0.5); HT29 (9.1) [44] \\
\hline 23 & Laurencia pacifica Kylin [45]Laurencia okamurae Yamada [46] & 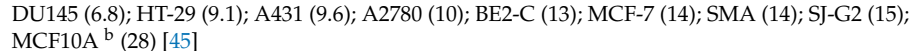 \\
\hline 24 & Laurencia pacifica Kylin [45]Laurencia okamurae Yamada [46] & HT-29 (15); DU145 (12); MCF10A b (46) [45] \\
\hline 25 & $\begin{array}{l}\text { Plocamium suhrii Kützing [47]Plocamium cartilagineum } \\
\text { (Linnaeus) P.S.Dixon [48,49] }\end{array}$ & WHCO1 (6.6) [47]; CFU (3.36) [48] \\
\hline 26 & $\begin{array}{l}\text { Plocamium suhrii Kützing [47]Plocamium cartilagineum } \\
\text { (Linnaeus) P.S.Dixon [48,49] }\end{array}$ & WHCO1 (9.9) [47] \\
\hline 27 & Plocamium suhrii Kützing [47] & WHCO1 (9.3) [47] \\
\hline 28 & $\begin{array}{l}\text { Plocamium suhrii Kützing [47]Plocamium cartilagineum } \\
\text { (Linnaeus) PS Dixon [499] Plocamium oreconum Doty [50] }\end{array}$ & WHCO1 (8.5) [47] \\
\hline 29 & Plocamium suhrii Kützing [47]Plocamium corallorhiza (Turner) & WHCO1 (7.9) [47] \\
\hline 30 & $\begin{array}{l}\text { Hooker \& Harvey [51] } \\
\text { Plocamium suhrii Kützing [47] }\end{array}$ & WHCO1 (8.4) [47] \\
\hline 31 & Plocamium cartilagineum (Linnaeus) P.S.Dixon $[48,49]$ & CFU (3.36) [48] HCT-116 (3.36) [52] \\
\hline 32 & Plocamium cartilagineum (Linnaeus) P.S.Dixon [48] & NCI-H460 (13) [48] \\
\hline 33 & Portieria hornemannii (Lyngbye) P.C.Silva [53] & HCT-116 $(0.92)[52,53]$ \\
\hline
\end{tabular}

a In this table are indicated the seaweed Latin botanical name used by the authors, which, according to the database AlagaeBase (http://www.algaebase.org), does not always correspond to a currently accepted name; ${ }^{\mathrm{b}}$ No-tumoral cell line; A2780 = Ovarian cancer cell line; A431 = Human skin carcinoma cell line; A549 = human alveolar basal epithelial adenocarcinoma cell line; BE2-C = Neuroblastoma cancer cell line; Bel7402 = Hepatocellular carcinoma; BGC-823 = Human gastric cancer cell line; CFU = human colon cancer cell line; DU 145 = Human prostate carcinoma cell line; HCT-8 = Epithelial human ileum cell line; HCT 116 = Human colon carcinoma; HeLa = Cervix adenocarcinoma cell line; HT-29= Human colon cancer cell line; KA3IT = Virally transformed form mouse cancer cell line; KB = Human nasopharynx carcinoma; MCF 10A = Human mammary epithelial normal cell line; NCI-H460 = Human lung carcinoma cell line; NIH3T3 = Cell line murine, fibroblast; NSCLC-N6 = Squamous cell lung carcinoma; NSCLCN6-L16 = Human non-small cell lung carcinoma cells; P388 = Mouse leukemia cell line; P388/DOX = Doxorubicin resistant mouse leukaemia cell line; SH-SY5Y = Human bone marrow neuroblastoma cancer cell line; SJ-G2 = Human glioblastoma cancer cell line; SMA = Murine glioblastoma cancer cell line; Vero = Kidney no-tumoral cell line; WHCO1 = Oesophageal cancer cell line. 


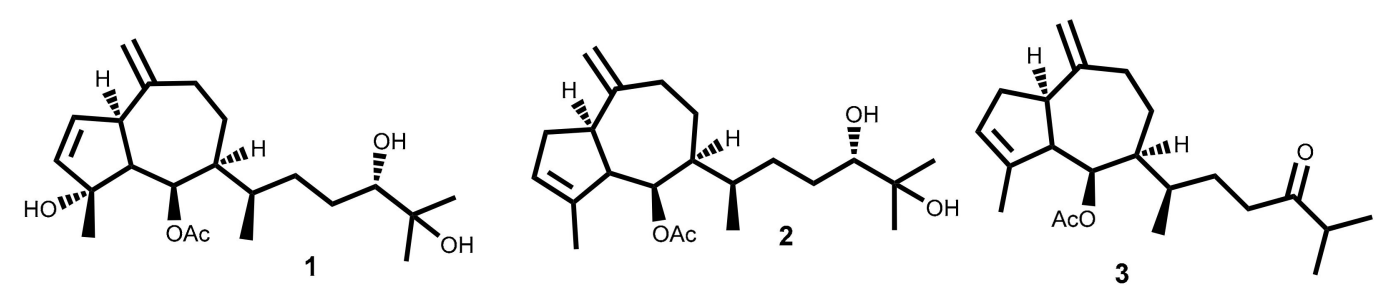

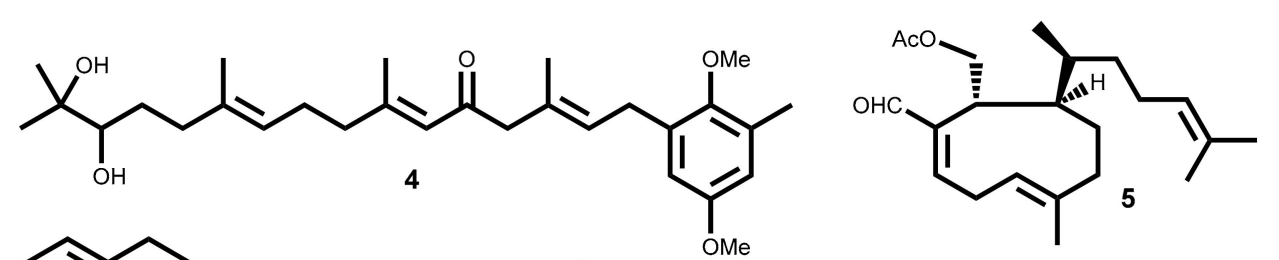

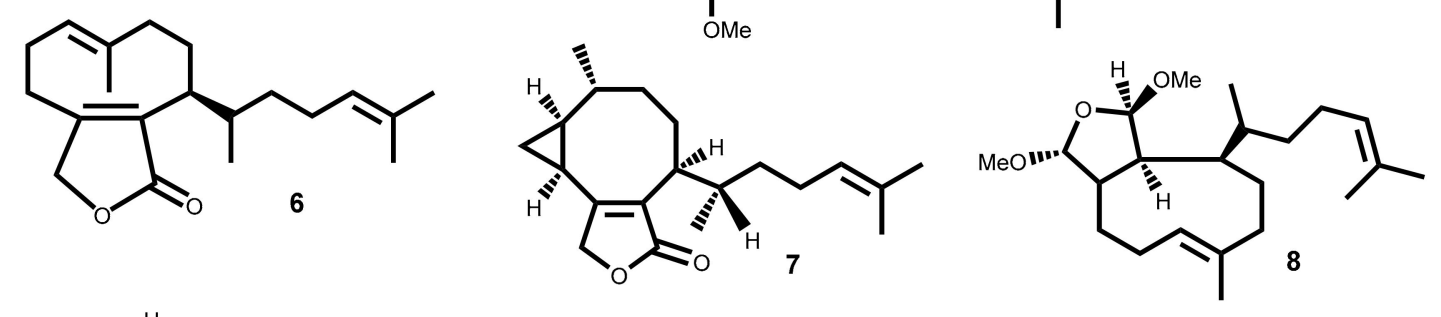

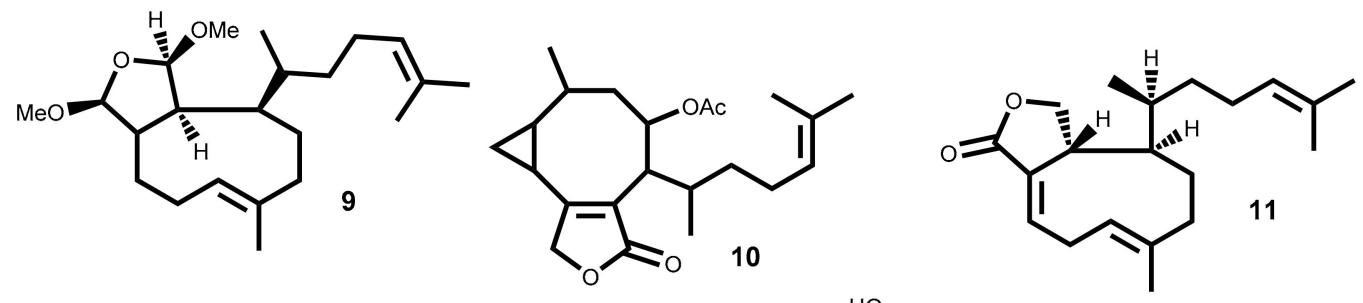

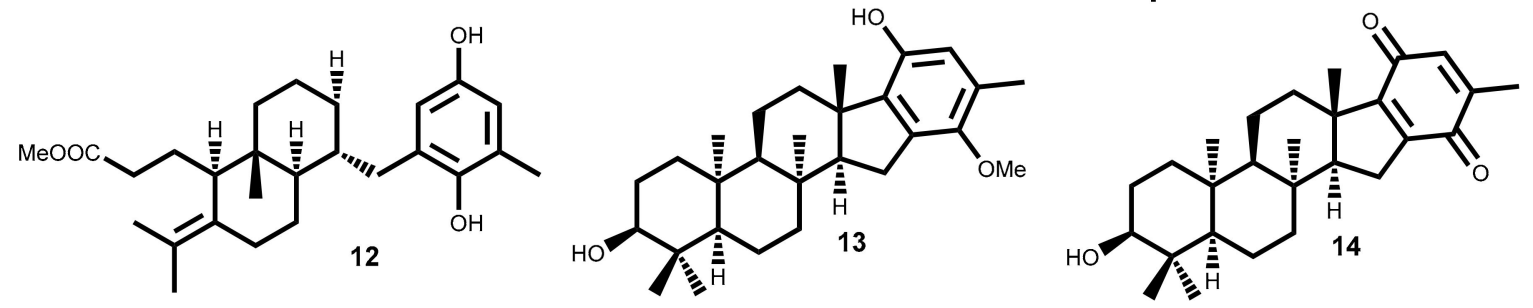

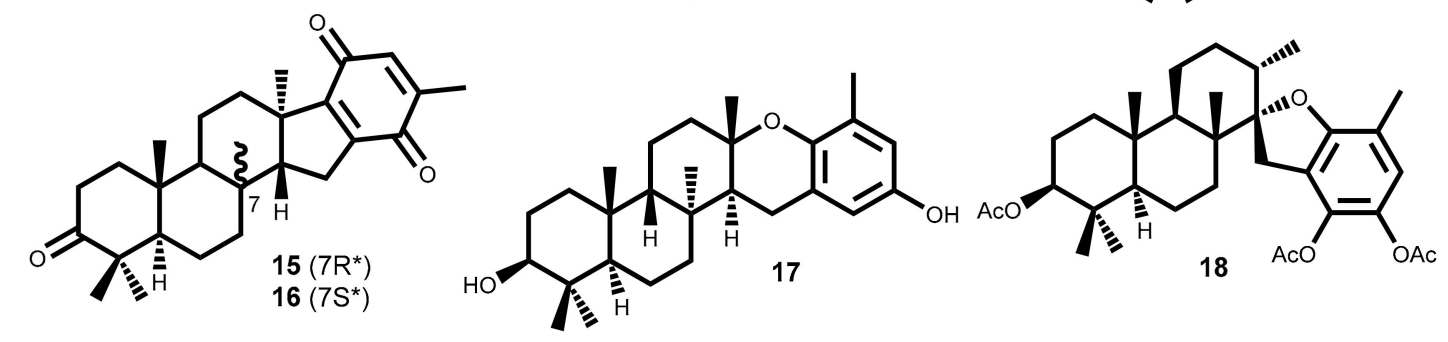

Figure 1. Cont. 


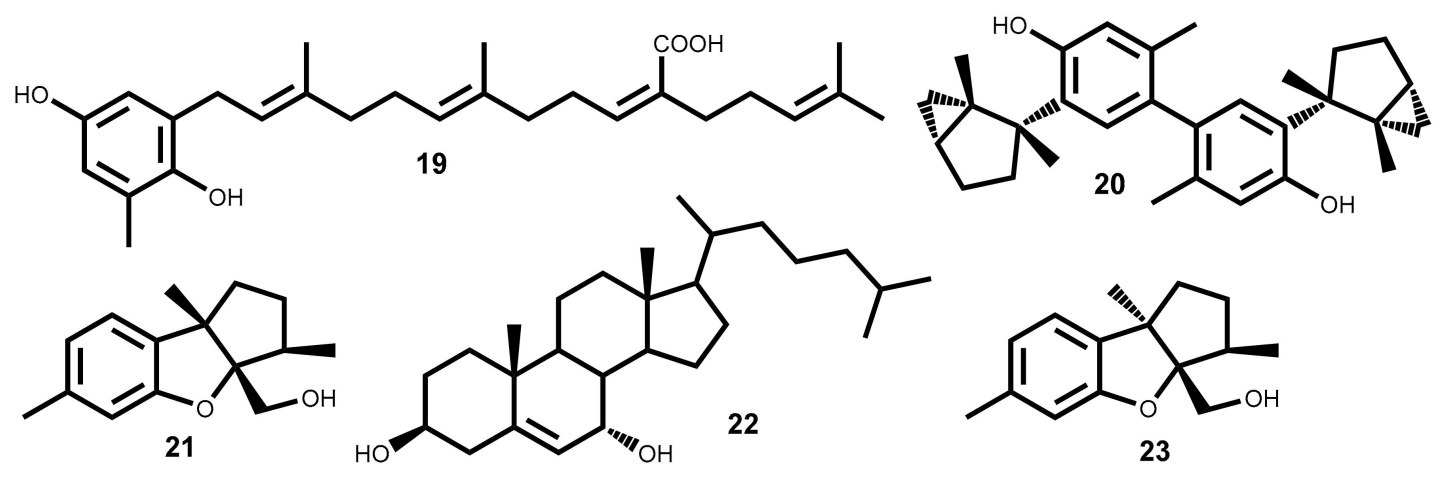

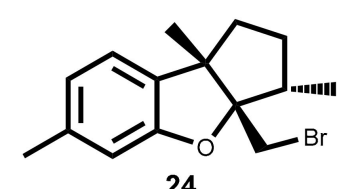

24

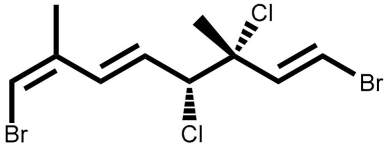

30<smiles>[R]C([R])=C[C@@](C)(Cl)[C@@H](Cl)/C=C/C(=C/Cl)C(Cl)Cl</smiles>

25. $R^{1}=H, R^{2}=B r\left(4 S^{*}\right)$

26. $R^{1}=H, R^{2}=B r\left(4 R^{*}\right)$

27. $R^{1}=B r, R^{2}=H\left(4 S^{*}\right)$

28. $R^{1}=R^{2}=H\left(4 S^{*}\right)$

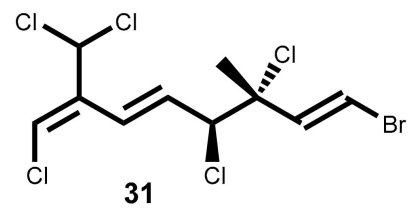

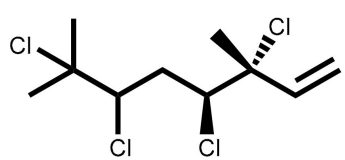

29

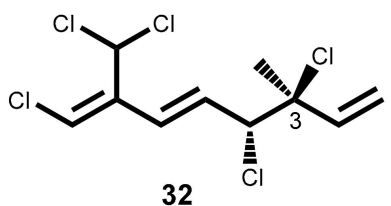<smiles>C=C(Cl)[C@@](Cl)(CBr)CC[C@@H](Br)C(C)(C)Cl</smiles>

Figure 1. Chemical structure of the terpenoids 1-33 isolated from seaweeds that presented significant cytotoxic activity.

From the 33 compounds shown in Table 1, 19 were isolated from brown seaweeds, whereas the remaining were isolated from red seaweeds. One third exhibit moderate activity $\left(10 \mu \mathrm{M}<\mathrm{IC}_{50}<15 \mu \mathrm{M}\right)$ against the cancer cell lines tested, while nearly 20 compounds exhibit significant cytotoxic activity, with $\mathrm{IC}_{50}$ values between 1 and $10 \mu \mathrm{M}$, at least against one of the cancer cell line tested. Among the latter, compounds 20 (laurebiphenyl) and 31 [(1E,5E,7E)-3,4-erythro-1-bromo-7-dichromethyl-3-methyl-3,4,8-trichlorooctatriene] can be emphasized, as they exhibit $\mathrm{IC}_{50}$ values between $1-5 \mu \mathrm{M}$ (Table 1 ).

The detailed analysis of the results compiled in Table 1 allowed choosing compound 22 (cholest-5-en-3 $\beta, 7 \alpha$-diol) as the most interesting one, due to the lower $\mathrm{IC}_{50}$ values $(<0.5 \mu \mathrm{M})$ against several cell lines. Additionally, also exhibited significant activity ( $\mathrm{IC}_{50}$ values $\left.5-9 \mu \mathrm{M}\right)$ against gastric and colon cancer lines. Compounds 11 (dictyolactone) and 33 (halomon) also should be highlighted due to their strong activity ( $\mathrm{IC}_{50}=0.99$ and $0.92 \mu \mathrm{M}$, respectively) against human non-small cell lung carcinoma cells (NSCLCN6-L16) and colon cancer cell line (HCT-116).

Unfortunately, very few compounds (only 6 out of 33) were subjected to selectivity studies and the more active ones, mentioned above, are not included in this lot. Debromoplysinol (23) and isoaplysin (24) are the most selective compounds, exhibiting cancer cell selectivity index of 4.1 and 3.8 , respectively, which means nearly four times more selective to the prostate carcinoma cells than to mammary epithelial no-tumoral cells. 
The results obtained in cytotoxic evaluations of hydroazulene skeleton type diterpenes isolated from the marine brown alga Polycladia myrica (S.G. Gmelin) Draima, Ballesteros, F. Rousseau \& T. Thibaut (syn. Cystoseira myrica (S.G. Gmelin) C. Agardh), where compounds 1-3 (Figure 1) were included, suggest that the presence of free hydroxyl groups is irrelevant [32].

Cytotoxicity of several meroditerpenes in different phases of the HeLa cell line growth cycle conducted by Gouveia et al. demonstrated that the HeLa cell line in log phase is 3.6 times more sensitive to cystoazorol A 4 than in lag phase [34]. Moreover, compound 4 showed a selectivity index higher than taxol, compound used as a positive control in the study [34].

From the Mediterranean brown algae Dilophus ligulatus (Kützing) Feldmann, which is the second genus that provides more compounds with interesting cytotoxic activity, can be emphasized the diterpenoids 5-11 that exhibit $\mathrm{IC}_{50}$ values lower than $15 \mu \mathrm{M}$ (Table 1). For example, murine leukemia cells (P-388) and P-388 doxorubicin resistant cell lines exhibit similar sensitivity ( $\mathrm{IC}_{50}=3.64$ to $13.3 \mu \mathrm{M}$ and $\mathrm{IC}_{50}=5.95$ to $12.9 \mu \mathrm{M}$, respectively) to diterpenes 6-9 and $\mathbf{1 1}$ [35]. Furthermore, compounds 6-11 exhibit higher cytotoxic activity against NSCLCN6-L16 $\left(\mathrm{IC}_{50} 0.99-6.85 \mu \mathrm{M}\right)$ than mercaptopurine $\left(\mathrm{IC}_{50}\right.$ 6.57-19.7 $\mu \mathrm{M}$ ), an effective anticancer drug used as positive control [35].

Both flabellinol 13 and flabellinone 14 (Figure 1), two polycyclic diterpenoids fused to an oxidized ring and biosynthetically related, were cytotoxic against NCI-H460 ( $\mathrm{IC}_{50} 9$ and $14 \mu \mathrm{M}$, respectively). The action mechanism is related with their ability to block the sodium channel activity [37]. From the brown algae Taonia atomaria (Woodward) J. Agardh collected in Central Aegean Sea were isolated two cyclic meroditerpenoids, atomarianone A 15 and atomarianone B 16, that are epimers at C-7 and both are analogues of flabellinone $\mathbf{1 4}$ (Figure 1). The different relative configuration at C-10 suggests that they are formed in a different diterpene cyclization pathway, nevertheless both exhibit significant cytotoxicity against two different lung cancer cell lines (Table 1) [38].

The antiproliferative properties of six meroditerpenoids were evaluated against human and non-human cancer cell lines and against no-tumoral cell line by Pereira et al. [39]. Epitaondiol 17 and stypotriol triacetate 18 (Figure 1) were the most active compounds, being the thrice-cloned neuroblastoma SH-SY5Y the most susceptible cell line tested ( $\mathrm{IC}_{50} 12.2$ and $14 \mu \mathrm{M}$, respectively), though much less active than vincristine $\left(\mathrm{IC}_{50}=0.03 \mu \mathrm{M}\right)$ used as positive control [39]. Furthermore, compounds $\mathbf{1 7}$ and $\mathbf{1 8}$ have lower selective index than other compounds tested, once at $25 \mu \mathrm{M}$ have more than $50 \%$ of proliferation inhibition on non-cancer Chinese hamster fibroblasts cell line (V79) [39].

The red alga of the genus Laurencia is collected in different parts of the world, but typically inhabit tropical oceans and are recognized for the biosynthesis of a high diversity of secondary metabolites, especially terpenoids mainly sesquiterpenoids, sterols and acetogennins. Some of these metabolites exhibit important pharmacological effects, from which cytotoxic can be highlighted [54-56]. From the compounds indicated in Table 1, five (20-24) were isolated from Laurencia species, the third genus with more compounds presented in Table 1 (after the genera Plocamium and Dilophus). Among the compounds isolated, the most active one is cholest-5-en-3 $\beta, 7 \alpha$-diol 22, the ones with the broadest action spectrum are laurebiphenyl 20, cholest-5-en-3 $\beta, 7 \alpha$-diol 22 and debromoaplysinol 23, and the most selective one is debromoaplysinol 23 (Table 1 ).

Isoaplysin $\mathbf{2 4}$ and debromoaplysinol $\mathbf{2 3}$ are two sesquiterpenes that differ in the presence of the C3a-hydroxymethyl instead of the C3a-bromomethyl moiety (Figure 1). Compound 23 displays enhanced selectivity and broad spectrum cytotoxicity relative to 24 which, according to the authors, suggests that the hydroxyl group could play a significant role in the cytotoxicity of this class of compounds [45]. However, these compounds also have different configuration around the $C 3$ and $\mathrm{C} 8 \mathrm{~b}$ chiral centers and that could explain the activity displayed. In fact, it is also observed that the stereochemistry of the $\mathrm{C} 8 \mathrm{~b}$ chiral center can play an important role in the drug-ligand interactions. This is well demonstrated by the strong activity of debromoaplysinol 23 when compared with debromoepiaplysinol 21 (Figure 1, Table 1). Compound 21 was tested against 5 cancer cell lines (lung, hepatic, cervix, gastric and ileum cancer cell lines) and shown to be much less active ( $\mathrm{IC}_{50}$ values greater than $15 \mu \mathrm{M}$ ) than compound 23 [44]. 
Plocamium is the genus with greater representativeness in Table 1 ( 8 secondary metabolites). The six halogenated monoterpenes 25-30 (Figure 1) isolated from the red macroalga Plocamium suhrii Kützing collected near Port Elizabeth, South Africa, showed great cytotoxicity $\left(\mathrm{IC}_{50}<10 \mu \mathrm{M}\right)$ against esophageal cancer cell line (WHCO1), even higher than the well-known clinical anticancer drug cisplatin $\left(\mathrm{IC}_{50}=13 \mu \mathrm{M}\right)$ [47]. Moreover, the low variation of the cytotoxicity level of compounds 25-30 against WHCO1 cell line $\left(\mathrm{IC}_{50}=6.6\right.$ to $\left.9.9 \mu \mathrm{M}\right)$ shows that the $\mathrm{C} 1$ double bond configuration (comparing compound 25 and 27), the $\mathrm{C} 4$ chiral center configuration (comparing compounds 25 and 26), and the presence of bromine atoms in the structure (comparing compounds 27 and 28), have little or no effect on the compounds' cytotoxicity.

Last year, was reported the isolation of halogenated monoterpenes 25, 31 and 32 from the red alga Plocamium cartilagineum (Linnaeus) P.S.Dixon (syn. Plocamium cartilagineum) collected in South Africa [48]. Additionally, the compounds' cytotoxic effects were evaluated and stereoisomers 25 and 31 exhibit identical and significant cytotoxicity against colon cancer cell line $\left(\mathrm{IC}_{50}=3.3 \mu \mathrm{M}\right)$ and low effect against lung cancer cell line (NCI-H460) [48]. In the attempt to find the possible mechanism of action was confirmed that none of the compounds have activity as sodium channel blockers or activators [48].

Halomon [6(R)-bromo-3(S)-bromomethyl)-7-methyl-2,3,7-trichloro-1-octene] 33 (Figure 1), an halogenated monoterpene isolated for the first time from Portieria hornemannii (Lyngbye) P. C. Silva, showed high cytotoxic activity against renal-, brain-, colon-derived solid tumor cell lines while leukaemia and melanoma cells are less sensitive to this compound [53]. This interesting case of differential cytotoxicity led this compound for in vivo and preclinical drug development. Unfortunately, several constraints such as low and variable natural content, and poor in vivo results, has hampered the clinical development of this compound. Conversely, the high interest of scientific community in the isolation of enough halomon 33 material lead to the reinvestigation of Portieria hornemannii (Lyngbye) P. C. Silva and to the consequent isolate of other halogenated monoterpenes. This fact allowed some structure/activity relationship studies that demonstrated no crucial role of the halogen at $\mathrm{C} 7$ neither the $\mathrm{C} 6$ nor $\mathrm{C} 7$ hybridization to the activity while the halogen atoms at $\mathrm{C} 6$ and $\mathrm{C} 2$ are crucial for the high cytotoxicity [57]. The mechanism of action of halomon-type monoterpenes have not been completely elucidated but it was demonstrated that halomon 33 possess potent inhibitory activity of the DNA methyltransferase-1 (DNMT-1) $\left(\mathrm{IC}_{50}=1.25 \mu \mathrm{M}\right)$, an enzyme responsible for methylation of cytosine residues residing at $\mathrm{CpG}$ sites. In fact, in many cancers, promoters of tumor suppressor genes are silenced by hypermethylation at CpG sites, and thus, the inhibition of DNMT-1 could potentially reverse tumor growth [58]. In truth, the interest in halomon 33 never fainted; the first total synthesis was achieved in 1998, halomon 33 was obtained in 13 steps with an overall yield of $13 \%$ [59] and in 2000 Sotokawa et al. described the synthesis of the racemic halomon, in three-steps $(25 \%)$ and poor selectivity [60]. Fifteen years later, the first selective method was described, which was also efficient [61]. Recently, halomon was synthesized using the previous method with some improvements in the enantioselectivity resulting also in preparation of several halomon-analogues and halogenated natural products [62]. Thus, conditions are created to advance with the clinical studies and/or development of new anticancer drugs based on the halomon scaffold.

Apart from the few cases mentioned above, the study of the compounds action mechanisms is vague. However, some studies on the mechanism of action of terpenoids extracted from seaweeds which are not indicated in Table 1 can be found in the literature. This means that the compounds showed lower activity or the $\mathrm{IC}_{50}$ value has not been reported. Nevertheless, information about possible mechanisms of action is important to understand the action of natural sesquiterpene. One example is the 14-keto-stypodiol diacetate 34 (Figure 2), a diterpenoid isolated from the seaweed Stypopodium flabelliforme with great structural similarity with compound 18 (Figure 1), whose cytotoxic effect on prostatic cancer cell proliferation (DU-145, $\mathrm{IC}_{50}=24 \mu \mathrm{M}$ ), and its action mechanism was studied [63]. 14-Keto-stypodiol diacetate 34 acts on microtubule assembly inhibition, induces mitotic arrest and has strong inhibition effect on plasminogen activator secretion [63]. These events 
are all correlated and affect the cell invasive capacity [64,65]. Moreover, the identification of the signaling pathway influenced by the microtubule cytoskeleton [66] may offer a source of novel anticancer treatments.

Laurinterol 35 (Figure 2), is a marine sesquiterpene isolated from a red alga Laurencia (Laurencia okamurae Yamada) [55], L. pacifica [45], Laurencia nidifica J. Agardh [67] that structurally is very similar to a part of laurebiphenyl 20 (Figure 1). Laurinterol 35 was reported for the first time as potential anticancer metabolite against melanoma cells $(\mathrm{B} 16 \mathrm{~F} 1)$ with $\mathrm{IC}_{50}$ value of $33.9 \mu \mathrm{M}$. and several studies were applied to understand its mechanism of action in B16F1 cells [55]. The results showed that 35 can induce apoptosis via activation of p53 transcription factor in melanoma cells and also increases the cell numbers in sub-G1 phase by DNA fragmentation [55].

Dactylone 36 (Figure 2), a natural marine halogenated sesquiterpenoid isolated from Laurencia glandulifera (Kützing) Kützing [68] was most recently evaluated for its effect on the mouse skin epidermal JB6 ${ }^{+} \mathrm{Cl} 41$ [69]. The dactylone 36 inhibits epidermal growth factor-induced transformation in JB6P ${ }^{+} \mathrm{Cl} 41$ cells, induces G1-S cell progression arrest and apoptosis of tumor cells. Also, decreases the expression of cyclin D3 and Cdk4 and cause the suppression of phosphorylation of the Rb protein of JB6P ${ }^{+} \mathrm{Cl} 41$ cells at $\mathrm{Ser}^{780}$, Ser ${ }^{807 / 811}$ and Ser ${ }^{795}$ in a dose-dependent manner. Similar inhibitory effects on phenotype expression were observed in the human tumor SK-MEL-28, HCT-116 and H460 cell lines [69]. Although this study didn't present the $\mathrm{IC}_{50}$ values, they should, in our opinion, be presented herein because the cancer-preventive properties and some details of the dactylone $\mathbf{3 6}$ molecular mechanism of action can be important to understand the action of other natural sesquiterpene.

The last example, is mertensene 37 (Figure 2), a polyhalogenated monoterpene isolated from the red alga Pterocladiella capillacea (S.G. Gmelin) Santelices \& Hommersand, that inhibit the viability of two human colorectal adenocarcinoma cell lines HT29 [70]. The results showed that mertensene 37 effect is correlated with the activation of mitogen-activated protein kinase (MAPK) extracellular signal-regulated kinase (ERK)-1/-2, serine/threonine-specific protein kinase (Akt) and nuclear factor-kappa B (NF-K $\mathrm{B}$ ) pathways. In cell cycle mertensene-induced $\mathrm{G} 2 / \mathrm{M}$ arrest which was associated with a decrease in the phosphorylated form of the anti-tumor transcription factor $p 53$, retinoblastoma protein $(\mathrm{Rb}), \mathrm{cdc} 2$ and chkp2. In apoptosis, mertensene triggers a caspase-dependent apoptosis by activation of caspase-3, the cleavage of poly (ADP-ribose) polymerase (PARP) and increased expression level of death receptor-associated protein TRADD [70].

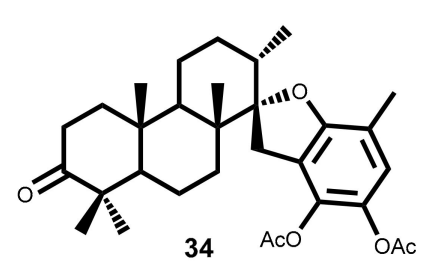

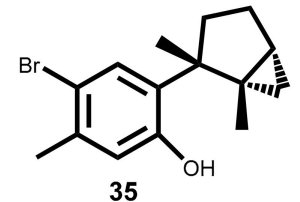

35

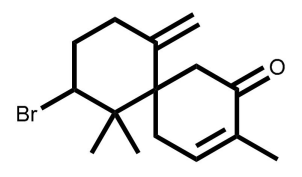

36

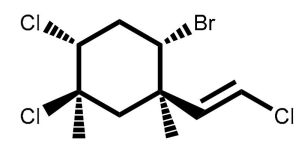

37

Figure 2. Seaweed terpenoids, 34-37, with relevant studies on its cytotoxic action mechanism.

The results discussed above confirm the role of terpenoids isolated from different species of brown and red alga as potential cancer chemotherapeutic and/or chemopreventive agents, against a large panel of cancer cells. However, deeper research to understand structure/activity relationships and to evaluate their cytotoxicity in no-tumoral cells is necessary. Furthermore, the most promising isolated metabolites should be evaluated in in vivo studies.

\subsection{Carotenoid}

Fucoxanthin 38 (Figure 3) is an orange-colored pigment tetraterpenoid belonging to xanthophylls subclass of carotenoids, that contributes to more than $10 \%$ of the total of carotenoids in nature, 
and being brown seaweeds their richest source in marine ecosystems [71-73]. Some of the examples of macroalgae that are excellent sources of this carotenoid are Undaria pinnatifida (Harvey) Suringar [74,75], Ectocarpus siliculosus (Dillwyn) Lyngbye [73], Saccharina japonica (Areschoug) C.E. Lane, C. Mayes, Druehl \& G.W. Saunders (syn Laminaria japonica Areschoug) [76], Sargassum fulvellum (Turner) C. Agardh and Hizikia fusiformis (Harvey) Okamura [72].

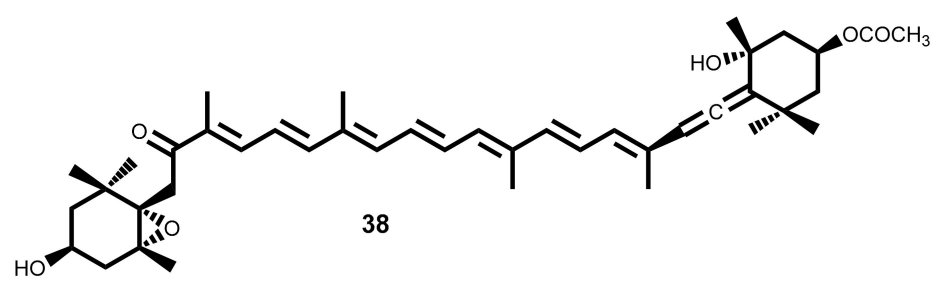

Figure 3. Chemical structure of fucoxanthin isolated from seaweeds.

The beneficial effects of fucoxanthin are widely described in the literature and are scientifically proven. In fact, the fucoxanthin have a very broad application ranging from prevention to treatment of cardiovascular diseases, oxidative stress, diabetes, obesity, hypertension, anti-inflammatory [20,24,25,77-79]. It also exhibits cytotoxic and anti-proliferative effects against a large number of cancer cell lines [80-83]. Fucoxanthin is clearly a great candidate for chemopreventive and/or chemotherapeutic use in the cancer battle. This can be concluded from the excellent review published by Satomi [83], where the antitumor and cancer-preventive effects of fucoxanthin are discussed and systematized. Herein we resume the main experimental evidences of fucoxanthin cytotoxic and/or antiproliferative effects (Table 2) as well as the main accepted wisdom about fucoxanthin mechanisms of action in different cancer cell lines.

Table 2. In vitro cytotoxic activity and action mechanism of fucoxanthin isolated from seaweeds.

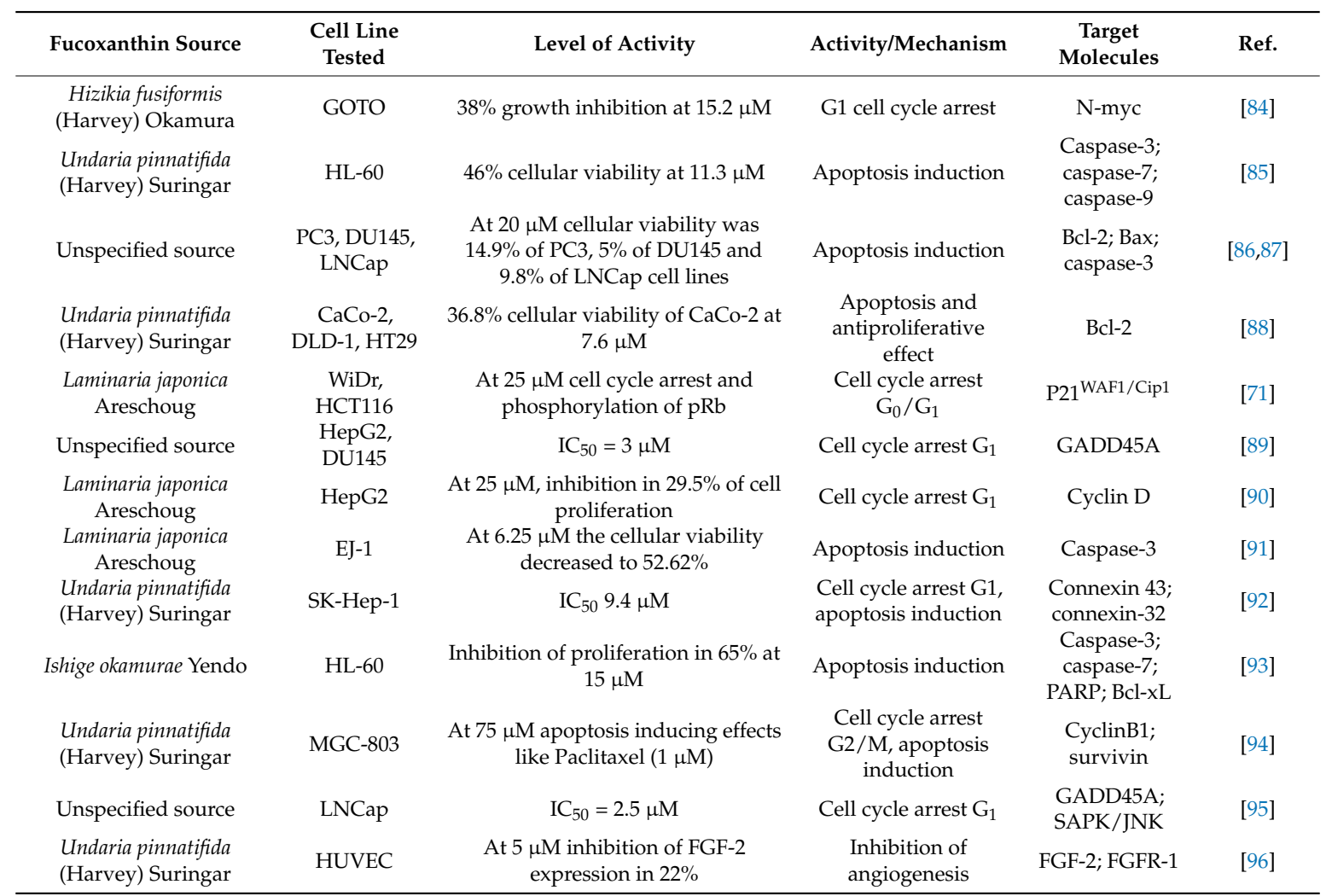


Table 2. Cont.

\begin{tabular}{|c|c|c|c|c|c|}
\hline Fucoxanthin Source & $\begin{array}{l}\text { Cell Line } \\
\text { Tested }\end{array}$ & Level of Activity & Activity/Mechanism & $\begin{array}{c}\text { Target } \\
\text { Molecules }\end{array}$ & Ref. \\
\hline Unspecified source & $\mathrm{T} 24$ & $\begin{array}{l}\text { Induced apoptosis at } 40 \mu \mathrm{M} \text { and } \\
\text { proliferation inhibition at } 5-10 \mu \mathrm{M}\end{array}$ & $\begin{array}{l}\text { Apoptosis induction; } \\
\text { Cell cycle arrest G1 }\end{array}$ & $\begin{array}{l}\text { Caspase-3; } \\
\text { cyclin D1; } \\
\text { cyclin E }\end{array}$ & [97] \\
\hline Unspecified source & U87, U251 & $\begin{array}{c}\text { At } 25 \mu \mathrm{M} \text { the cellular viability } \\
\text { decreased } 52 \% \text { and } 43 \% \text { in U } 87 \text { and } \\
\text { U251, respectively }\end{array}$ & $\begin{array}{l}\text { Apoptosis induction. } \\
\text { Inhibition of } \\
\text { invasion and } \\
\text { migration }\end{array}$ & $\begin{array}{c}\text { Caspase-3; } \\
\text { caspase-9; } \\
\text { cleaved-PARP; } \\
\text { P38-MMP-2/9 }\end{array}$ & [98] \\
\hline Unspecified source & $\mathrm{SiHa}$ & $\begin{array}{l}\text { Strong synergistic effect from } \\
\text { combination with TRAIL }\end{array}$ & Apoptosis induction & $\begin{array}{l}\text { Caspase-3; } \\
\text { Bcl-2; Bax }\end{array}$ & [99] \\
\hline $\begin{array}{l}\text { Undaria pinnatifida } \\
\text { (Harvey) Suringar }\end{array}$ & SGC7901 & $\mathrm{IC}_{50}=9.80 \pm 0.94(48 \mathrm{~h})$ & $\begin{array}{l}\text { Apoptosis and } \\
\text { autophagy induction }\end{array}$ & $\begin{array}{c}\text { Beclin-1; } \\
\text { caspase-3; Bcl-2 }\end{array}$ & [100] \\
\hline
\end{tabular}

Bcl-xL = B-cell lymphoma extra-large; CaCo-2 = Human colon adenocarcinoma cell line; DLD-1 = Human colon adenocarcinoma cell line; DU-145 = Human prostate carcinoma cell line; EJ-1= Human lymphoma; FGF = Fibroblast growth factors; GOTO = Human neuroblastoma cell line; HepG2 = Human liver hepatocarcinoma cell line; HCT-116 = Human colon carcinoma cell line; HL-60 = Human leukaemia cell line; HT-29 = Human colorectal adenocarcinoma cell lines; HUVEC = Human umbilical vein endothelial cells; LNCap = Human prostate carcinoma cell line; MGC-803 = Human gastric carcinoma cell line; N-myc $=$ Proto-oncogene protein; $\mathrm{P} 21^{\mathrm{WAF} 1 / \mathrm{Cip} 1}=\mathrm{Cyclin}$-dependent kinase inhibitor 1; PARP = poly-ADP-ribose polymerase; PC-3 = Human prostate adenocarcinoma cell line; SAPK/JNK = c-Jun N-terminal kinases; SiHa = Human cervix uteri cell line; SGC7901 = Human gastric cancer cell line; SK-Hep-1 = Human endothelial adenocarcinoma cell line; T24 = Human bladder carcinoma cell line; U87 and U251 = Human primary glioblastoma cell line; $\mathrm{WiDr}=$ Human colorectal adenocarcinoma cell lines.

The studies summarized in Table 2 suggest that fucoxanthin exerts its antiproliferative and cancer-preventing effects by modulating the expression of various cellular molecules and cellular signal transduction pathways, being the most cited mechanisms: (i) induction of G1 cell-cycle arrest, independent of the apoptosis induction. Involving also, one or more factors, such as the increase of $\mathrm{p} 15^{\mathrm{INK} 4 \mathrm{~B}}, \mathrm{p} 21^{\mathrm{WAF} 1 / \mathrm{CIP} 1}$ and $\mathrm{p} 27^{\mathrm{KIP} 1}$ and connexin $32 / 43$ expression, the activation of MAPK pathways, the decrease of myelocytomatosis (MYCN) proto-oncogene expression and suppression of NF-kB activity; (ii) induces a caspase dependent apoptosis accompanied by an increase of reactive oxygen species (ROS) generation and mitochondrial membrane permeability while occur decrease in B-cell lymphoma-extra large (BCL-xL), cellular inhibitors of apoptosis protein (CIAP)1, CIAP2, X-linked inhibitor of apoptosis protein (XIAP) and surviving proteins level, reduction in phosphoinositide 3-kinase (PI3K) and AKT activity and downregulation of signal transducer and activator of transcription 3 (STAT3)/epidermal growth factor receptor (EGFR ) signaling; (iii) induces metastasis inhibition by decrease the matrix metallopeptidase 9 , cluster of differentiation 44 (CD44) and CXCR4.

In addition to the wide effects of fucoxanthin 38 , the toxicological studies conducted in male and female mice showed that single doses (1000 or $2000 \mathrm{mg} / \mathrm{kg}$ ) or repeated treatment (500 or $1000 \mathrm{mg} / \mathrm{kg}$ for 30 days) of this pigment, was neither toxic nor promotes histological alteration in mice [101].

The research involving fucoxanthin $\mathbf{3 8}$ is currently more focused on its use in combination therapy for the treatment of leukemia, aiming to solve adverse side effects such as the development of resistance and effects on no-tumor cells [102]. Other recent studies involve the development of new delivery systems such as encapsulation-based delivery systems $[103,104]$ and combination with nanoparticles $[105,106]$. The objective of these new approaches is to overcome fucoxanthin $\mathbf{3 8}$ poor in vivo properties, such as low bioavailability and low chemical stability.

It is recognized that fucoxanthin $\mathbf{3 8}$ is metabolized to fucoxanthinol in the gastrointestinal tract by digestive enzymes, such as lipase and cholesterol esterase and then absorbed into intestinal cells [107]. Thus, fucoxanthinol seems to be the in vivo bioactive compound [82]. In fact, some authors studied the fucoxanthinol activity and described its ability to induces apoptosis on human colon adenocarcinoma cell line (CaCo-2), human breast adenocarcinoma cell line (MCF-7), human leukemia cell line (HL-60), human adenocarcinoma breast cell line (MDA-MB-231) [108,109], to promote antiproliferative effects on PC3 and T cell leukemia $[110,111]$ and to induce apoptosis in body-cavity-based lymphoma cell line (BCBL-1) and primary effusion lymphoma cell line (TY-1) cells and G1 cell cycle arrest [112]. 


\subsection{Phenolic Compounds}

Phenolic compounds are composed of a single aromatic ring bearing one or more hydroxyl group to a polymeric structure of this simple unit and exhibit a large broad of biological activities [113-115]. The most common subclasses of polyphenols in seaweeds are halogenated phenols, catechins, flavonols, and phlorotannins, being this last more common in brown seaweed while bromophenols, polyphenolics compounds with one or more bromine substituents, are most commonly found in red seaweeds $[28,113,116,117]$. Polyphenols presence and concentrations in seaweeds can be linked to environmental factors $[118,119]$, but is also dependent of the seaweed species $[120,121]$.

\subsubsection{Phlorotannins}

Phlorotannins are described as polyphenolic secondary metabolites formed by polymerization of phloroglucinol 39 (Figure 4) monomer units highly hydrophilic and with a wide range of molecular sizes $[113,122]$. Based on their interlinkage, phlorotannins can be classified in subclasses, such as phlorethols, fucols, fucophlorethols, eckols, fuhalols and carmalols [122-124].

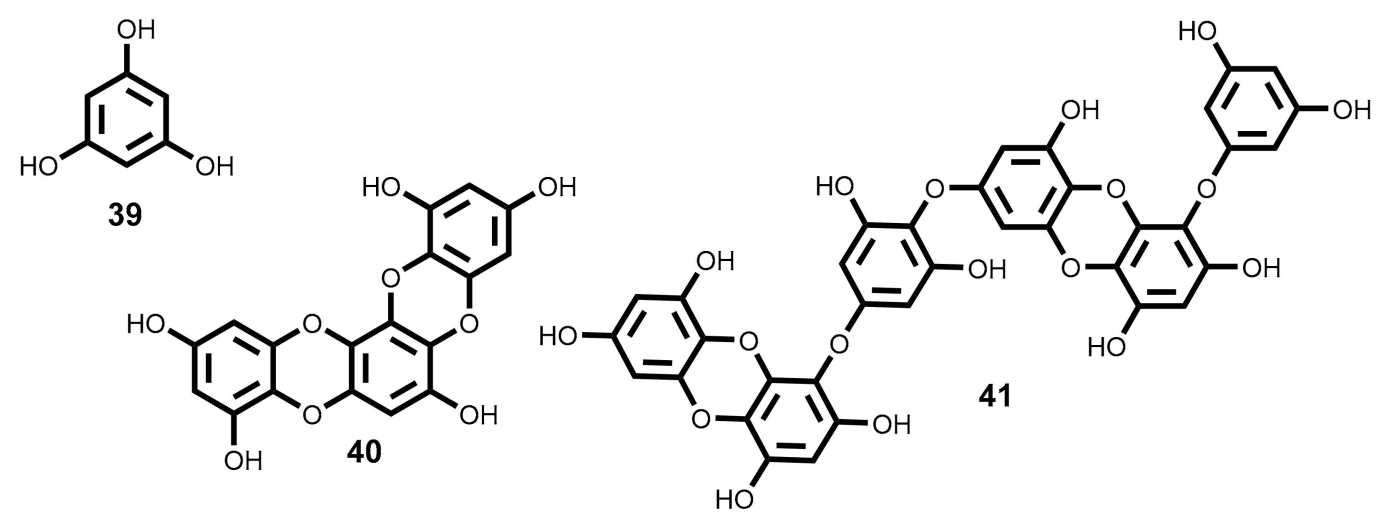

Figure 4. Chemical structure of phloroglucinol 39 and phlorotannins 40 and 41 isolated from seaweeds.

There is evidence that phlorotannins and its derivatives play important roles as anticancer metabolites, acting in different hallmarks of cancer such as proliferative signaling, metastasis, cell cycle, resistance to cell death, evasion, angiogenesis and evasion of growth suppressors. These metabolites can also be considered as chemopreventive agents due to their antioxidant effect, once oxidative stress may act in cancer initiation, promotion and progression $[113,117,125,126]$.

From the brown seaweeds Ecklonia Cava Kjellman [127] and Ecklonia stolonifera Okamura [128] were isolated several phloroglucinol derivatives. One of them, dioxinodehydroeckol 40 (Figure 4), showed moderate antiproliferative activity against breast cancer cell lines, MCF-7 and MDA-MB-231, being MCF-7 more sensitive than MDA-MB-231. Dioxinodehydroeckol 40 inhibited 53\% of MCF-7 cells proliferation at $10 \mu \mathrm{M}$ [127] and induced the cells' apoptosis through NF- $\kappa B$ dependent pathway, by an increase in the caspases- 3 and -9 activities and cleavage of PARP, accompanied by activation of p53 and Bax and Bcl-2 inhibition [127]. The phlorotannin 40 (Figure 4), also exhibits protective activity against ultraviolet radiation B (UVB)-induced apoptosis of HaCaT cells (treatment of HaCaT cells post-UVB exposure with compound 40 allowed $72 \%$ less of cell death). Apparently, phlorotannin 40 can modulate the Bax/Bcl-2 and caspases expression [129]. This is an interesting result because indicates its potential to protect skin against UVB effects.

Dieckol 41 (Figure 4), the major component of Ecklonia Cava Kjellman [127], was described as an anti-metastatic compound, having the ability to regulate the metastasis-related genes action on MCF-7 cells, inhibiting the expression of MMP-9 (matrix metalloproteinase-9) and VEGF (vascular endothelial growth factor), and stimulated the expression of TIMP-1 and -2 (tissue inhibitor of metalloproteinase) [130]. This phlorotannin also exhibits a significant pro-apoptotic activity on the ovarian cancer cell line (SKOV3) associated with ROS production. The action mechanisms studied 
demonstrate that dieckol 41 triggered the activation of caspase-3, -8 and -9 via ROS production and the regulation of AKT and p38 signalling [131].

Phloroglucinol 39 (Figure 4), although is the base-unit of phlorotannins, was also assayed against breast cancer (MCF7, SKBR3 and BT549) stem-like cells which are largely responsible for return of breast cancer [132]. The authors demonstrated that treatment with phloroglucinol 39 suppresses sphere forming ability and anchorage-independent colony formation in breast cancer cells by decreasing the expression of Sox2, CD44, Oct4, Notch2 and $\beta$-catenin, the cancer stem-like cell regulators. Moreover, treatment with compound 39 sensitized breast cancer cells to anticancer drugs such as cisplatin, etoposide, and taxol as well as to ionizing radiation. This work proposed that phloroglucinol prevents disease relapse [132]. In the same year, the authors published another study highlighting the antimetastatic effects of phloroglucinol 39 on breast cancer cells (BT549 and MDA-MB-231) through inhibition of the PI3K/AKT and the rat sarcoma (RAS)/RAF-1/ERK mitogenic pathways thereby suppressing epithelial-mesenchymal cell transition [133].

\subsubsection{Bromophenols}

Since, the isolation of the first bromophenols from red algae Neorhodomela larix (Turner) Masuda (syn. Rhodomela larix (Turner) C. Agardh) [134], many novel bromophenols were isolated [135-139] and some of them, as it is indicated in Table 3, are very interesting cytotoxic compounds. The most interesting features will be discussed below and their structures are depicted in Figure 5.

Table 3. Bromophenols with potential cytotoxic activity isolated from seaweeds.

\begin{tabular}{|c|c|c|}
\hline Metabolites & Sources & Cell Lines Tested $\left(\mathrm{IC}_{50}\right.$ Value $\left.\mu \mathrm{M}\right)$ \\
\hline 42 & $\begin{array}{l}\text { Vertebrata lanosa (Linnaeus) T.A. Christensen } \\
\text { [137], Neorhodomela larix (Turner) Masuda } \\
\text { [134,140], Odonthalia corymbifera (S.G. Gmelin) } \\
\text { Greville [135] }\end{array}$ & DLD-1 (14.6); HCT-116 (14.1) [137] \\
\hline 43 & $\begin{array}{l}\text { Vertebrata lanosa (Linnaeus) T.A.Christensen [137], } \\
\text { Osmundaria serrata (Suhr) R.E. Norris [138] }\end{array}$ & DLD-1 (13.5); HCT-116 (2.51) [137] \\
\hline 44 & Vertebrata lanosa (Linnaeus) T.A. Christensen [137] & DLD-1 (12.4); HCT-116 (1.32) [137] \\
\hline 45 & Rhodomela confervoides (Hudson) P.C. Silva [141] & $\begin{array}{l}\text { KB (12.5); Bel7402 (12.9); A549 (14.4); HELF a (25.9) } \\
\text { [141] }\end{array}$ \\
\hline 46 & Leathesia marina (Lyngbye) Decaisne [142,143] & $\begin{array}{l}\text { A549 (2.5); BGC823 (8.8); MCF-7 (2.7); Bel7402 (4.8); } \\
\text { B16-BL6 (7.3); HT-1080 (6.6); A2780 (2.7) [142,143] }\end{array}$ \\
\hline 47 & $\begin{array}{l}\text { Leathesia marina (Lyngbye) Decaisne [142], } \\
\text { Rhodomela confervoides (Hudson) P.C. Silva [144] }\end{array}$ & $\begin{array}{l}\text { A549 (1.8); BGC823 (3.8); MCF-7 (2.7); HCT-8 (2.2) } \\
\text { [142] }\end{array}$ \\
\hline 48 & Leathesia marina (Lyngbye) Decaisne [142,143] & $\begin{array}{l}\text { BGC823 (4.6); MCF-7(3.4); Bel7402 (5.5); HCT-8 (2.8); } \\
\text { B16-BL6 (3.3), HT-1080 (7.2); A2780 (7.1) [142,143] }\end{array}$ \\
\hline 49 & Leathesia marina (Lyngbye) Decaisne [142,143] & $\begin{array}{l}\text { BGC823 (8.6); B16-BL6 (15.4); HT-1080 (10.3) } \\
{[142,143]}\end{array}$ \\
\hline 50 & Leathesia marina (Lyngbye) Decaisne [142,143] & $\begin{array}{l}\text { A549 (5.4); MCF-7 (4.6); Bel7402 (7.4); HCT-8 (5.9); } \\
\text { HT-1080 (8.2); A2780 (8.6) }[142,143]\end{array}$ \\
\hline 51 & Leathesia marina (Lyngbye) Decaisne [143] & $\begin{array}{l}\text { A549 (1.6); BGC823 (3.3); MCF-7 (2.5); HCT-8 (1.9); } \\
\text { B16-BL6 (3.2); A2780 (3.8) [143] }\end{array}$ \\
\hline
\end{tabular}

${ }^{\text {a }}$ No-tumoral cell line A2780 = Ovarian carcinoma cell line; A549 = Human lung carcinoma cell line; B16-BL6 = Murine melanoma cell line; Bel7402 = Hepatocellular carcinoma cell line; BGC-823 = Human gastric cancer cell line; DLD-1 = Human colon adenocarcinoma cell line; HCT-8= Human colon adenocarcinoma cell line; HCT-116 = Human colon carcinoma cell line; HELF = Non-tumoral human embryo lung fibroblasts cell line; HT-1080 = Human fibrosarcoma cell line; KB = Human nasopharynx carcinoma; MCF-7= Human breast adenocarcinoma cell line. 


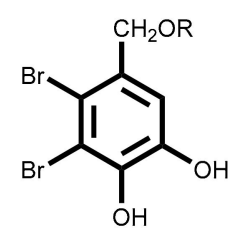

42. $\mathrm{R}=\mathrm{CH}_{3}$ 43. $\mathrm{R}=\mathrm{CH}_{2} \mathrm{CH}_{3}$ 44. $\mathrm{R}=\mathrm{CH}_{2} \mathrm{CH}_{2} \mathrm{CH}_{3}$<smiles>CCOCc1cc(O)c(O)c(Br)c1Cc1cc(O)c(O)c(Br)c1Br</smiles>

48<smiles></smiles><smiles>Oc1cc(Cc2cc(O)c(O)c(Br)c2Br)c(Br)c(Br)c1O</smiles>
47<smiles>COCc1cc(O)c(O)c(Br)c1Cc1cc(O)c(O)c(Br)c1Br</smiles><smiles>Oc1cc(Cc2c(O)c(O)c(Br)c(Br)c2Br)c(Br)c(Br)c1O</smiles>

Figure 5. Chemical structure of bromophenols 42-51 isolated from seaweeds.

The literature review carried out and summarized in Table 3 shows that there are 10 compounds belonging to the subclass of the bromophenols that exhibit cytotoxic activity with $\mathrm{IC}_{50} \leq 15 \mu \mathrm{M}$. Among these, mention should be made to compounds 46, 48, and 50 for their relevant cytotoxicity $\left(\mathrm{IC}_{50} \leq 9 \mu \mathrm{M}\right)$ against a wide range of at least 6 cancer cell lines, and a particular emphasis to compound 51, which exhibits the highest cytotoxic activity against the six cancer cell lines, lung, gastric, breast, melanoma, ovarian and colon cell lines $\left(\mathrm{IC}_{50} \leq 3.8 \mu \mathrm{M}\right.$ ) (Figure 5 and Table 3). Compound 47 exhibit identical cytotoxic activity but only against 4 tumor cell lines ( $\mathrm{IC}_{50} \leq 3.8 \mu \mathrm{M}$ against lung, gastric, breast and colon cancer cell lines). Compound 44 is the one with the lowest $\mathrm{IC}_{50}$ value in Table 3 ( $\mathrm{IC}_{50}$ $=1.32 \mu \mathrm{M})$ against a colon cancer cell line, whereas compounds' 51 and 47 present the lower values against a lung cancer cell line ( $\mathrm{IC}_{50}=1.6$ and $1.8 \mu \mathrm{M}$ respectively).

Unfortunately, from the works cited in Table 3 only the work performed by Lijun et al. evaluates the compounds selectivity [141]. They test the compounds, under the same experimental procedure, against the human embryo lung fibroblasts cell line.

The report of the values obtained with positive controls (anticancer drugs in clinical use) and evaluate in the same conditions is also rare. As far as we could find only Shoeib et al. report such data [137], however we should emphasize that the absence of these data significantly reduces the impact of the published results. The compounds 43 and 44 exhibit higher cytotoxic activity against HCT-116 $\left(\mathrm{IC}_{50}=2.51\right.$ and $1.32 \mu \mathrm{M}$, respectively) than the 5-fluorouracil $\left(\mathrm{IC}_{50}=4.93 \mu \mathrm{M}\right)$, an effective anticancer drug used as positive control. On the other hand, HCT-116 cell line is 5-fold and 9-fold, respectively, more sensitive to the compounds 43 (ethyl ether lanosol) and 46 ( $n$-propyl ether lanosol) than to compound 42 (methyl ether lanosol) while the human colon adenocarcinoma cell line (DLD-1) is much less sensitive to any of these compounds. Studies of structure-activity relationship showed that the activity is influenced by the number and position of bromine atoms, as well as the number of hydroxyl groups and aliphatic side chain [137].

$\mathrm{Wu}$ et al. [145] described the inhibitory effects of compound 47, bis (2,3-dibromo-4,5-dihydroxy-phenyl)-methane, in the proliferation, migration and invasion of

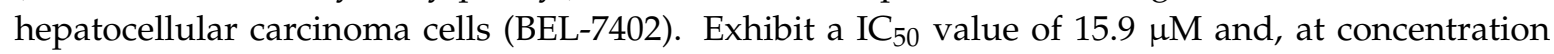
of $9.1 \mu \mathrm{M}$, the cell adhesion to fibronectin and collagen IV as well as cell migration and invasion decrease significantly, while at $18.2 \mu \mathrm{M}$ a complete inhibition of the migration and MMP-2 and MMP-9 expression occurs. Moreover, compound $\mathbf{4 7}$ inhibits the focal adhesion kinase (FAK), a protein required for cell transformation and invasion [145]. The compound 47 also inhibits multiple angiogenesis processes, including endothelial cell sprouting, migration, proliferation, and tube formation. It seems 
to be a potent and selective inhibitor of the tyrosine kinase receptor and exhibiting multi effects of inhibition. Moreover, at $10 \mu \mathrm{M}$ inhibit the activities of FGFR2 and FGFR3, VEGFR2 and PDGFR $\alpha$ factors and decreases the phosphorylation of PKB/Akt and eNOS, as well as the NO production [146].

The inhibitory effect of compounds 48 and 49 against the protein tyrosine kinase (PTK) with over-expression of the proto-oncogene $c-k i t$ was evaluated and the results showed significant inhibition ratio of this protein $(80.1 \%$ and $71.4 \%$ respectively) [147].

In 2012, Liu et al. [148] selected the compound 50 (bis(2,3-dibromo-4,5-dihydroxybenzyl) ether), a cytotoxicity compound against a wide range of cancer cell lines ( $\mathrm{IC}_{50} \leq 9 \mu \mathrm{M}$, Table 3$)$, for detailed analysis of its effect on K562 cell line. The authors demonstrated that the mitochondrial pathway was involved in the bromophenol $\mathbf{5 0}$ induced apoptosis. In fact, bromophenol $\mathbf{5 0}$ induces S phase arrest and inhibits topoisomerase I activity followed by apoptosis. It is interesting to mention that compound 50, contrary to the mechanism of the topoisomerase I inhibitor campthotecin, was not able to stimulate the formation of topoisomerase I-DNA complex or able to intercalate DNA. These facts suggest a different inhibition mechanism [148]. Considering that the current topoisomerase I inhibitors exhibit significant side effects [149] and the uniqueness of compound $\mathbf{5 0}$ structure, its significant cytotoxic activity against a broad range of cancer cell lines coupled with its distinct mechanism of action, indicate that compound 50 may, undoubtedly, be a leading compound for the development of a new generation of anticancer topoisomerase I inhibitors.

Qi et al. also studied the bromophenol 50 effects on angiogenesis and detected that it can significantly repress the human umbilical vein endothelial cells (HUVEC) cells proliferation without induced apoptosis. Can also decrease migration and tube formation, without effect on the performed vascular tube, via inhibiting VEGF signal systems [150].

\subsection{Alkaloids}

Alkaloids isolated from seaweeds include indoles and indoles analogues, quinone, 2-phenylethylamine and 2,7-naphthyridine derivatives, however the most common ones belong to the indole and 2-phenylethylamine groups [151]. The indole type is concentrated in Rhodophyta (red seaweeds) while halogenated alkaloids, mainly bromine- and chloride-containing, are dominant in Chlorophyta (green seaweeds) [152]. Indole type alkaloids are also important because they represent a quarter of all alkaloids that are regarded as promising compounds in the development of new drugs.

The lophocladine B 52 (Figure 6) is a 2,7-naphthyridine alkaloid isolated from red alga Lophocladia sp. collected in the Fijan Islands [153]. The cytotoxicity of this molecule was evaluated against NCI-H460 (lung cancer cell line) and MDA-MB-435 (used by the authors as a human breast cancer model but currently considered as a human melanoma model [154]). Lophocladine B 52 exhibits significant cytotoxic effect against and MDA-MB-435 cell line $\left(\mathrm{IC}_{50}=3.1 \mu \mathrm{M}\right)$, causing a major reduction of cells in the G1 and S phases with G2/M cell cycle arrest [153]. Moreover, the analyses of lophocladine B 52 effects on cellular microtubes and actin filaments in A-10 cells (used as vascular smooth muscle cells model) showed that this metabolite acts as microtubules inhibitor with no loss of actin filament [153]. In the same year Lotter et al. reported that lophocladine B 52 is also able to inhibit human leukemia cells (HL-60) $\left(\mathrm{IC}_{50}=1 \mu \mathrm{M}\right)$ [155].

The well-known potential of the antitubulin compounds as effective anticancer agents, for example taxol and vincristine, spread the interest of the scientific community in the synthesis of lophocladine $B$ 52 or derivatives, seeking new and more potent antitumor agents and/or structure activity relationship studies [155-158]. To date, only two of the synthesized compounds (simplified isoquinolines isoquinoline-triazole derivatives) exhibit better cytotoxicity $\left(\mathrm{IC}_{50}=10.14\right.$ and $\left.12.76 \mu \mathrm{M}\right)$ than lophocladine B 52 against hepatic cancer (HepG2) and cervical cancer (HeLa) cell lines $\left(\mathrm{IC}_{50}=89.5\right.$ and $>100 \mu \mathrm{M}$ ) [158]. However, the synthesis of lophocladine B 52 allowed the conclusion that the cytotoxic level depends on the $\mathrm{C} 1$ substituent. For example, tert-amine is less potent than primary- and secondary-amines [157]. 

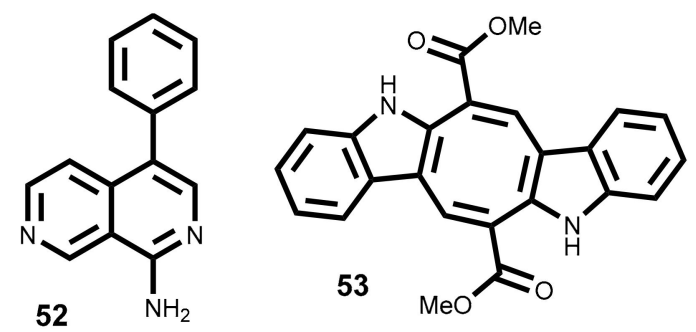

Figure 6. Chemical structure of cytotoxic alkaloids isolated from seaweeds.

Indole alkaloids have exhibited a wide array of biological activities and the frameworks produced by marine species are often very different from those produced by terrestrial species [159-161]. One interesting example is the bisindole caulerpin or caulerpine 53 (Figure 6), isolated mainly from green algae genus Caulerpa [161,162] but also from Codium decorticatum (Woodward) M. Howe [163] and Halimeda incrassata (J. Ellis) J.V. Lamouroux [164]. And also found in some red algae such as Chondria armata (Kützing) Okamura [165], Laurencia dendroidea J. Agardh [syn. Laurencia majuscula (Harvey) A.H.S. Lucas] and Caloglossa leprieurii (Montagne) G. Martens [166].

Some of the abovementioned seaweeds are invasive species and the study of their chemical entities can contribute to suggesting a possible use for that biomasses, being the isolation of valuable chemicals one of the most explored uses. In this context, caulerpin $\mathbf{5 3}$ is among the most studied metabolites. Unfortunately, caulerpin 53 effects on cell growth/viability are not very interesting, $\mathrm{IC}_{50}$ values $\geq 20 \mu \mathrm{M}$ against some cancer cell lines (T47-D, MCF-7, MDA-MB-231, PC3 DU145, HMEC, HCT116, HT29, LOVO and SW480) [167,168].

Even though, caulerpin 53 action mechanism was studied and it was proved that caulerpin 53 inhibits hypoxia-inducible factor 1 (HIF-1), an important target in cancer therapy [167]. The results suggested that caulerpin 53 at concentration of $10 \mu \mathrm{M}$ and under hypoxic conditions blocked the induction of HIF- $1 \alpha$ protein, the HIF-1 oxygen-regulated subunit, while at concentration of $30 \mu \mathrm{M}$, it disrupts mitochondrial ROS-regulated HIF-1 activation and downstream HIF-1 pathway [167]. Caulerpin 53 also exhibits effect on tumor cell migration once it suppressed the migration of metastatic MDA-MB-231 cells in a concentration-dependent manner, being the better results observed at $30 \mu \mathrm{M}$ [167].

Caulerpin 53 overpowers the mitochondrial respiratory at complex II and increases ROS production in cisplatin-resistant $\mathrm{C} 13$ ovarian cancer cells, while it has no effect on the complexes I, III and IV [169], suggesting that some derivatives could be good candidates for the treatment of cisplatin-resistant cancer, once ovarian cancer cisplatin resistant cells are characterized by reduced oxygen consumption and increased dependence on glucose [170].

More recently, the anticancer effect of caulerpin 53 against LOVO cancer cell line was evaluated, and the results showed a cytotoxic effect with $\mathrm{IC}_{50}=20 \mu \mathrm{M}$ [168]. The mechanism of action study indicates that caulerpin 53 inhibits oxidative phosphorylation (OXPHOS), that is inhibits the metabolic pathway in which cells use enzymes to oxidize nutrients to release energy. LOVO cells are one example of those cells that are less glycolytic and more depended on OXPHOS to produce adenosine triphosphate (ATP). It was also demonstrated that in combination therapy, caulerpin $\mathbf{5 3}$ can be used with the glycolytic inhibitor 3-bromopyruvate to prevent LOVO cellular proliferation [168].

\section{Secondary Metabolites from Seaweeds with In Vivo Antitumor Activity}

Some of the secondary metabolites mentioned in the previous section were subjected to in vivo evaluations, not as much as it is recommended. Those studies, due to their significance, will be herein presented and discussed.

Preliminary in vivo evaluation of halomon 33 (Figure 1) showed that daily treatments ( $5 \times$ doses of $50 \mathrm{mg} / \mathrm{kg}$ ) in an ip/ip xenograft model with highly aggressive U251 brain cancer showed $40 \%$ of success. However, research was stopped due to insufficient amount of halomon 
33 to perform more essential tests. Both attempts to extract more material from the natural sources and development of efficient synthetic procedures demonstrate that the amount obtained could not be use by pharmaceutical industry [57].

The in vivo inhibitory effect of fucoxanthin 38 (Figure 3) in duodenal carcinogenesis was demonstrated using mice with duodenal carcinogenesis, which was induced by $N$-ethyl- $N^{\prime}$-nitro- $N$-nitrosoguanidine. The mice were treated with fucoxanthin 38 [oral administration of $0.005 \%$ solution of fucoxanthin in drinking water], during 4 and 16 weeks. This in vivo study demonstrates that fucoxanthin 38 inhibits ornithine decarboxylase (ODC) activity [171], an enzyme whose activity is induced in response to cell growth stimuli and is highly expressed in diseases such as inflammation and cancer being not only a biomarker for cancer but also a potential target for its therapy [172].

Fucoxanthin 38 was also evaluated on melanin synthesis in vivo and was found that topical application (once a day to the back skin of the mice shortly after UVB irradiation) of an ointment (mixture of fucoxanthin at $0.01,0.1$ and $1 \%$ in white petrolatum) and oral treatment [fucoxanthin at $0.1,1$ and $10 \mathrm{mg} / \mathrm{kg}$ b.w. in water with $5 \%$ acacia, given once a day, $2 \mathrm{~h}$ before UVB irradiation $\left(160 \mathrm{~mJ} / \mathrm{cm}^{2}\right)$ for seven days followed by increased UVB $\left(320 \mathrm{~mJ} / \mathrm{cm}^{2}\right)$ irradiation for seven more days], suppressed skin mRNA expression related to melanogenesis [173]. Identical effect was observed on UV-induced skin pigmentation in guinea-pigs [173]. In conclusion these results suggest that fucoxanthin 38 exhibits in vivo anti-pigmentary activity, in UVB-induced melanogenesis, by topical or oral application. This effect of fucoxanthin 38 may be due to suppression of prostaglandin (PG) E2 synthesis and melanogenic stimulant receptors (neurotrophic, PGE2 and melanocyte stimulating hormone expression) [173].

Finally, fucoxanthin 38 at 25, 50 and $100 \mathrm{mg} / \mathrm{kg}$ b.w. oral administration dose, once per day for 1 week, exhibits the ability to induce apoptosis of sarcoma 180 (S180) [174]. The in vivo study was performed using male Kunming mice and the results indicated that treatment with fucoxanthin 38 remarkably reduce the expression of EGFR in the tumor tissue when compared with the model control group, suggesting that down-regulation of STAT3/EGFR signaling appeared to be involved in the in vivo anti-tumor effect and apoptosis induction [174].

Bald/c athymic female nude mouse with ovarian carcinoma induced by subcutaneously inoculating $5 \times 10^{6}$ SKOV3 cells, were used for in vivo studies of anticancer effects of dieckol 41 (Figure 4). For 4 consecutive weeks, the experimental group of mice is treated with dieckol $4 \mathbf{1}$ (50 and $100 \mathrm{mg} / \mathrm{kg}$ b.w.) or cisplatin ( $3 \mathrm{mg} / \mathrm{kg}$ b.w.) three times per week [131]. The results demonstrated that dieckol 41 suppressed tumor growths compared with the control group without any significant adverse effect in the SKOV3-bearing mouse model [131].

In 2017, the efficacy of dieckol 41 (oral admistration of $40 \mathrm{mg} / \mathrm{kg}$ b.w. dose for 15 weeks) as anticancer against $N$-nitrosodiethylamine (NDEA)-induced hepatocarcinogenesis in male albino Wistar rats was evaluated [175]. The treatment with dieckol 41 caused the suppression of the NDEA-initiated hepatocarcinogenesis by modulation of xenobiotic-metabolizing enzymes with modulation of cell proliferation and induction of apoptosis via the mitochondrial pathway. The inhibition of invasion and angiogenesis also observed was evidenced by the decrease of both MMP-2 and MMP-9 activities as well as the decrease of the vascular endothelial growth factor (VEGF) expression. Dieckol 41 also exerts anticancer effects via inhibition of the pro-inflammatory transcription factors NF-kb and COX2 [175].

Phloroglucinol 39 (Figure 4) (at $25 \mathrm{mg} / \mathrm{kg}$ b.w. dose administrated four times at alternate days) suppresses colony formation and in vivo tumorigenicity in BT549 breast cancer cells [132]. Tumor were formed by subcutaneous inoculation of $1 \times 10^{6}$ sphere-cultured BT549 breast cancer cells into athymic Bald/c female nude mice and phloroglucinol 39 decreased dramatically the tumor volume, suggesting that this secondary metabolite inhibits tumorigenic capacity by targeting cancer stem-like cells and/or non-cancer stem-like cells (CSCs) [132].

To study the phloroglucinol 39 effect on metastatic breast cancer (MDA-MB-231) in vivo, the model metastatic MDA-MB-231 cells injected into fourth mammary fat pad of NOD scid gamma (NSG) mice 
was used [133]. The treatment with phloroglucinol $39(25 \mathrm{mg} / \mathrm{kg}$ b.w.) administrated four times on alternate days, attenuated the primary tumor formation in mammary fat pads, and attenuated the lung metastasis and the expression levels of vimentin (VIM) and SLUG proteins [133]. Similarly, to the in vitro data, treatment with phloroglucinol 39 decreased phosphorylation of AKT and ERK, consequently treated mice survive longer than the control mice [133].

The in vivo study to evaluate the activity of bromophenol $\mathbf{5 0}$ (Figure 5) was carry on zebrafish model, an ideal model used in screening of anti-angiogenic agents. At a concentration of $25 \mu \mathrm{M}$, bromophenol 50 inhibited the sub-intestinal vessel (SIV) formation in $49.5 \%$, confirming it inhibitory activity against angiogenesis. The results also suggest that bromophenol $\mathbf{5 0} \mathrm{can}$, in concentration dependent manner, produce toxic effects towards the zebrafish development [150].

Our final example is the in vivo effect of caulerpin 53 (Figure 6), in combination with 3-bromopyruvate, on athymic nude mouse model bearing SW480 implanted xenografts. The combination therapy of 3-bromopyruvate and caulerpin $53(30 \mathrm{mg} / \mathrm{kg}$ b.w.) displayed remarkable tumor regression. Complementary analysis demonstrated that proliferating cell nuclear antigen (PCNA) and phosphorylated mammalian target of rapamycin (p-mTOR) expression was significantly inhibited in this combined therapy, showing the key role of adenosine monophosphate-activated protein kinase (AMPK)/mTOR pathway in the anticancer activity of caulerpin 53 [168].

\section{Conclusions}

In this review the in vitro activities of 53 secondary metabolites isolated from brown, red and green seaweeds are presented and discussed. The mechanisms of action, structure/activity relationship and, in the cases that was possible, the in vivo studies were also discussed. From literature published in the last 30 years, were selected the secondary metabolites that exhibit cytotoxic activity against tumor cell lines with $\mathrm{IC}_{50}$ values lower than $15 \mu \mathrm{M}$. The compounds reported belong mainly to the terpenoids class, followed in much smaller number by compounds of bromophenols class, phlorotannins and alkaloids.

The diterpene 11 (dictyolactone), the sterol 22 (cholest-5-en-3 $\beta, 7 \alpha$-diol) and the halogenated monoterpene 33 (halomon) are the only reported compounds with sub-micromolar activity $\left(\mathrm{IC}_{50} \leq 0.9 \mu \mathrm{M}\right)$ against at least one cancer cell line, while laurebiphenyl 20, a dimeric sesquiterpene of the cyclolaurane-type, and the halogenated monoterpene 31, [(1E,5E,7E)-3,4-erythro-1-bromo-7-dichromethyl-3-methyl-3,4,8-trichlorooctatriene] are relevant because they exhibit $\mathrm{IC}_{50}$ values between 1-5 $\mu \mathrm{M}$ against 6 cell lines (lung, cervix, gastric, hepatic, ileum, colon cancer cell lines). Of the remaining compounds, it is noteworthy the bromophenol 51, which exhibits high cytotoxic activity $\left(\mathrm{IC}_{50} \leq 3.8 \mu \mathrm{M}\right)$ against the lung, gastric, breast, colon, melanoma and ovarian cancer cell lines, the bis (2,3-dibromo-4,5-dihydroxy-phenyl)-methane 47 with identical cytotoxic activity against the first 4 tumoral cell lines and $n$-propyl ether lanosol 46 the most active bromophenol $\left(\mathrm{IC}_{50}=1.32 \mu \mathrm{M}\right.$ against colon cancer cell line), in fact more active than the 5-fluorouracil. These are, as far as we could find, the most promising secondary metabolites isolated from seaweeds and reported in the literature.

It should be emphasized that most of the promising compounds outlined herein belong to classes of secondary metabolites that are not biosynthesized in terrestrial species, being the most evident ones the halogenated terpenes and bromophenols. This fact reinforces the importance of the marine environment in general and the seaweeds in particular as a source of potentials new anticancer drugs.

Nevertheless, several studies remain to be performed. Only a few compounds (only 9 out of 53 presented) were subjected to selectivity studies, and none of them correspond to the most promising ones. Also, the in vivo studies are scarce (5 out of 53 cytotoxic compounds reviewed), except for fucoxanthin 38, dieckol 41 and phloroglucinol 39. But this compound advanced studies can be explained because they are already recognized as having high pharmacological potential for the prevention/treatment for example cardiovascular diseases [20,25].

An added value of these compounds that can be detected by this literature survey is clearly shown by the in vitro and in vivo works demonstrating different mechanisms of action and targets. 
These facts suggest that the seaweeds' secondary metabolites may be used to develop new anticancer agents with distinct ways of action.

Surprisingly, the most advanced studies on mechanisms of action and/or in vivo studies were not performed with the more promising compounds. Most likely because they are scarce in nature and/or their synthesis is not yet accomplished. Even so, we believe that some of the above-discussed compounds exhibit activities that justify greater attention from the scientific community.

Author Contributions: A.M.L.S. and D.C.G.A.P. conceived and revised the paper, D.H.A.R. made the research and wrote the first draft.

Funding: This research received no external funding.

Acknowledgments: We would like to thank also to University of Azores, University of Aveiro, Organic Chemistry Natural Products and Food Stuffs (QOPNA) unit, and Azorean Biodiversity Group (GBA) for technical support. We would also like to thank the Portuguese National Funds, through FCT-Fundação para a Ciência e a Tecnologia, and as applicable co-financed by the FEDER within the PT2020 Partnership Agreement by funding the Organic Chemistry Research Unit (QOPNA) (UID/QUI/00062/2013) and the cE3c centre (UID/BIA/00329/2013) for financial support. D.H.A. Rocha also thanks FCT for her grant (SFRH/BD/68991/2010).

Conflicts of Interest: The authors declare no conflict of interest. The founding sponsors had no role in the writing of the manuscript, and in the decision to publish it.

\section{Abbreviations}

\begin{tabular}{|c|c|}
\hline Akt & Serine/Threonine-Specific Protein Kinase \\
\hline AMPK & Adenosine Monophosphate-Activated Protein Kinase \\
\hline ATP & Adenosine Triphosphate \\
\hline BALB & "Bagg Albino" \\
\hline Bax & B-Cell Lymphoma 2-Associated X Protein \\
\hline BCBL-1 & Body-Cavity-Based Lymphoma Cell Line \\
\hline BCL-xL & B-Cell Lymphoma-Extra Large \\
\hline BT549 & Human Carcinoma Breast Epithelial Cell Line \\
\hline b.w. & Body Weight \\
\hline CD44 & Cluster of Differentiation 44 \\
\hline cdc2 & Cell Division Cycle Protein 2 \\
\hline CDK4 & Cyclin-Dependent Kinase 4 \\
\hline CpG & Cytosine Nucleotide Followed by A Guanine Nucleotide \\
\hline CIAP & Cellular Inhibitors of Apoptosis Protein \\
\hline $\mathrm{COX}$ & Cyclooxygenase \\
\hline CSCs & Cancer Stem-Like Cells \\
\hline CTX & Cyclophosphamide \\
\hline CXCR4 & CXC Motif Chemokine Receptor 4 \\
\hline DMSO & Dimethyl Sulphoxide \\
\hline DNA & Deoxyribonucleic Acid \\
\hline DNMT-1 & DNA Methyltransferase-1 \\
\hline EGFR & Epidermal Growth Factor Receptor \\
\hline eNOS & Endothelial Nitric Oxide Synthase \\
\hline ERK & Extracellular Signal-Regulated Kinase \\
\hline FAK & Focal Adhesion Kinase \\
\hline FGFR & Fibroblast Growth Factor Receptor \\
\hline G1 phase & Gap 1 Phase \\
\hline GTP & Guanosine-5'-triphosphate \\
\hline $\mathrm{HaCaT}$ & Aneuploid Immortal Keratinocyte Cell Line \\
\hline HIF-1 $\alpha$ & Hypoxia-Inducible Factor 1-Alpha \\
\hline $\mathrm{IC}_{50}$ & The Half Maximal Inhibitory Concentration \\
\hline K562 & Human Chronic Myelogenous Leucemia Cell Line \\
\hline LOVO & Human Colon (Supraclavicular Lymph Node Metastasis) \\
\hline M & Mitosis \\
\hline MAPK & Mitogen-Activated Protein Kinase \\
\hline MDA-MB-231 & Human Adenocarcinoma Breast Cell Line \\
\hline MMP & Matrix Metalloproteinase \\
\hline mRNA & Messenger Ribonucleic Acid \\
\hline
\end{tabular}




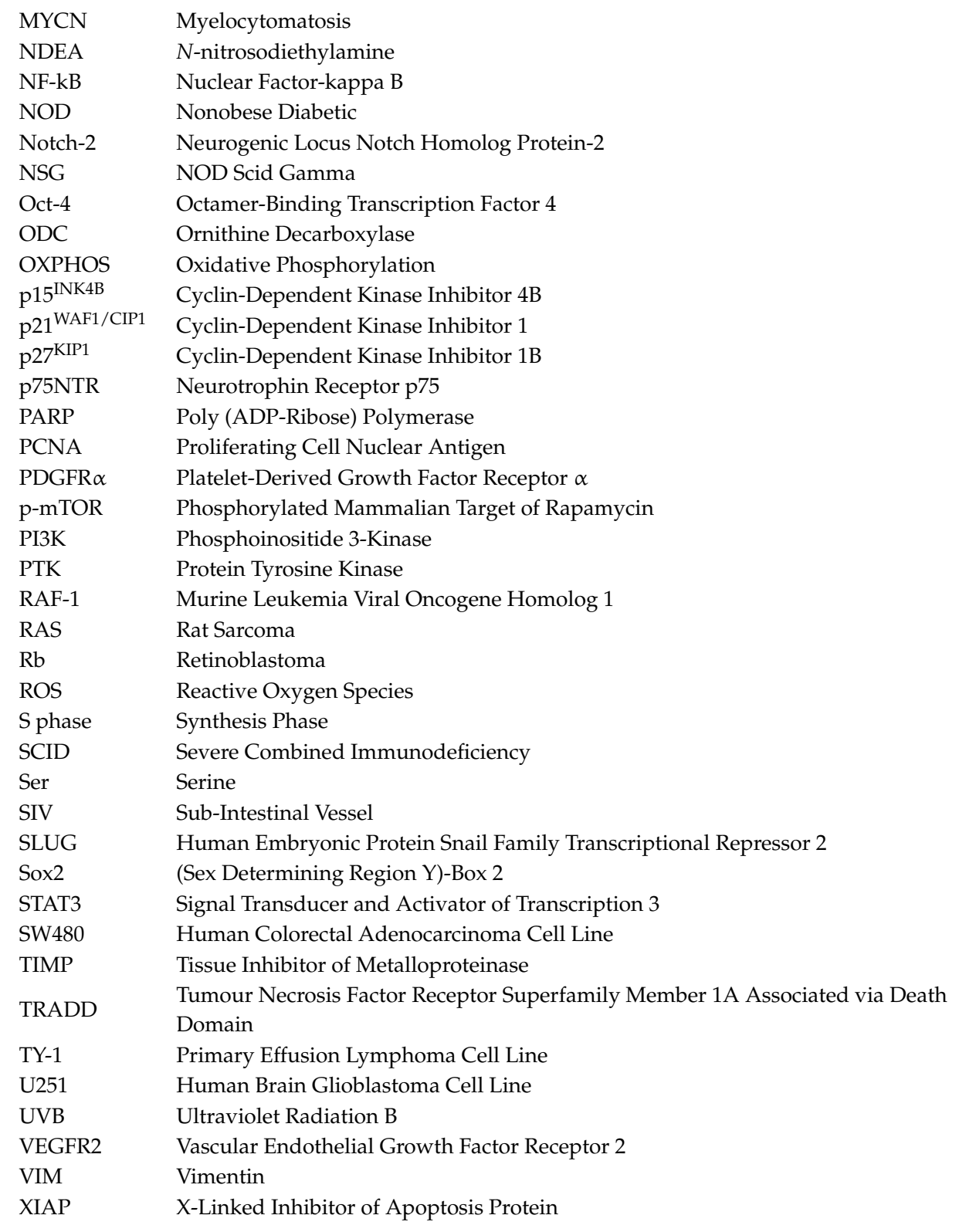

\section{References}

1. IARC, International Agency for Research on Cancer, World Health Organization. Press Release $\mathrm{n}^{\circ} 263$, 12 September 2018. Available online: http:/ / gco.iarc.fr/today/home (accessed on 14 September 2018).

2. Bray, F. Transitions in human development and the global cancer burden. In World Cancer Report 2014; Stewart, B.W., Wild, C.P., Eds.; International Agency for Research on Cancer: Lyon, France, 2014; pp. 54-68. ISBN 978-92-832-0443-5.

3. WCRFI, World Cancer Research Fund International. Available online: http://www.wcrf.org/int/cancerfacts-figures/worldwide-data (accessed on 30 June 2018).

4. Mullard, A. FDA approves first immunotherapy combo. Nat. Rev. Drug Discov. 2015, 14, 739. [CrossRef]

5. Nicolini, A.; Carpi, A.; Ferrari, P.; Biava, P.M.; Rossi, G. Immunotherapy and hormone-therapy in metastatic breast cancer: A review and an update. Curr. Drug Targets 2016, 17, 1127-1139. [CrossRef] [PubMed]

6. ASCO, American Society of Clinical Oncology. Available online: https:/ /www.asco.org/research-progress / reports-studies/clinical-cancer-advances-2018/advances-cancer-treatment (accessed on 14 September 2018).

7. Lartigue, J. Tumor heterogeneity: A central foe in the war on cancer. J. Community Support. Oncol. 2018, 16, 167-174. [CrossRef] 
8. Nikolaou, N.; Pavlopoulou, A.; Georgakilas, A.G.; Kyrodimos, E. The challenge of drug resistance in cancer treatment: A current overview. Clin. Exp. Metastasis 2018, 35, 309-318. [CrossRef] [PubMed]

9. Feinberg, A.P.; Ohlsson, R.; Henikoff, S. The epigenetic progenitor origin of human cancer. Nat. Rev. Genet. 2006, 7, 21-33. [CrossRef] [PubMed]

10. American Cancer Society. Cancer Facts and Figures 2017. Atlanta: American Cancer Society, 2017. Available online: https: / www.cancer.org/content/dam/cancer-org/research/cancer-facts-and-statistics / annual-cancer-facts-and-figures/2017/ cancer-facts-and-figures-2017.pdf (accessed on 30 June 2018).

11. Sun, W. Recent advances in cancer immunotherapy. J. Hemat. Oncol. 2017, 10, 96. [CrossRef] [PubMed]

12. Senapati, S.; Mahanta, A.K.; Kumar, S.; Maiti, P. Controlled drug delivery vehicles for cancer treatment and their performance. Signal Transduct. Target Ther. 2018, 3, 1-18. [CrossRef] [PubMed]

13. Ruiz-Torres, V.; Encinar, J.A.; Herranz-López, M.; Pérez-Sánchez, A.; Galiano, V.; Barrajón-Catalán, E.; Micol, V. An updated review on marine anticancer compounds: The use of virtual screening for the discovery of small-molecules cancer drugs. Molecules 2017, 22, 1037. [CrossRef] [PubMed]

14. Seca, A.M.L.; Pinto, D.C.G.A. Plant secondary metabolites as anticancer agents: Successes in clinical trials and therapeutic application. Int. J. Mol. Sci. 2018, 19, 263. [CrossRef] [PubMed]

15. Newman, D.J.; Cragg, G.M. Natural products as sources of new drugs from 1981-2014. J. Nat. Prod. 2016, 79, 629-661. [CrossRef] [PubMed]

16. Gamal, A.A.E. Biological importance of marine algae. Saudi Pharm. J. 2010, 18, 1-25. [CrossRef] [PubMed]

17. Boopathy, N.S.; Kathiresan, K. Anticancer drugs from marine flora: An overview. J. Oncol. 2010, $2010,18$. [CrossRef]

18. Pérez, M.J.; Falqué, E.; Domínguez, H. Antimicrobial action of compounds from marine seaweed. Mar. Drugs 2016, 14, 52. [CrossRef]

19. Wan-Loy, C.; Siew-Moi, P. Marine algae as a potential source for anti-obesity agents. Mar. Drugs 2016, 14, 222. [CrossRef] [PubMed]

20. Seca, A.M.L.; Pinto, D.C.G.A. Overview on the antihypertensive and anti-obesity effects of secondary metabolites from seaweeds. Mar. Drugs 2018, 16, 237. [CrossRef] [PubMed]

21. Rebours, C.; Marinho-Soriano, E.; Zertuche-González, J.A.; Hayashi, L.; Vásquez, J.A.; Kradolfer, P.; Soriano, G.; Ugarte, R.; Abreu, M.U.; Bay-Larsen, I.; et al. Seaweeds: An opportunity for wealth and sustainable livelihood for coastal communities. J. Appl. Phycol. 2014, 26, 1939-1951. [CrossRef] [PubMed]

22. Anis, M.; Ahmed, S.; Hasan, M.M. Algae as nutrition, medicine and cosmetic: The forgotten history, present status and future trends. World J. Pharm. Pharm. Sci. 2017, 6, 1934-1959. [CrossRef]

23. Gouveia, V.; Seca, A.M.L.; Barreto, M.C.; Pinto, D.C.G.A. Di-and sesquiterpenoids from Cystoseira genus: Structure, intra-molecular transformations and biological activity. Mini-Rev. Med. Chem. 2013, 13, 1150-1159. [CrossRef] [PubMed]

24. Peng, Y.; Hiu, J.; Yang, B.; Lin, X.-P.; Zhou, X.-F.; Yang, X.-W.; Liu, Y. Chemical composition of seaweeds. Seaweed Sustainability-Food and-Non-Food Applications, 1st ed.; Tiwari, B.K., Troy, D., Eds.; Elsevier: London, UK, 2015; pp. 79-124.

25. Cardoso, S.M.; Pereira, O.R.; Seca, A.M.L.; Pinto, D.C.G.A.; Silva, A.M.S. Seaweeds as preventive agents for cardiovascular diseases: From nutrients to functional foods. Mar. Drugs 2015, 13, 6838-6865. [CrossRef] [PubMed]

26. Sun, Y.; Hou, S.; Song, S.; Zhang, B.; Ai, C.; Chen, X.; Liu, N. Impact of acidic, water and alkaline extraction on structural features, antioxidant activities of Laminaria japonica polysaccharides. Int. J. Biol. Macromol. 2018, 112, 985-995. [CrossRef] [PubMed]

27. Folmer, F.; Jaspars, M.; Dicato, M.; Diederich, M. Photosynthetic marine organisms as a source of anticancer compounds. Phytochem. Rev. 2010, 9, 557-579. [CrossRef]

28. Murphy, C.; Hotchkiss, S.; Worthington, J.; McKeown, S.R. The potential of seaweed as a source of drugs for use in cancer chemotherapy. J. Appl. Phycol. 2014, 26, 2211-2264. [CrossRef]

29. Alves, C.; Silva, J.; Pinteus, S.; Gaspar, H.; Alpoim, M.C.; Botana, L.M.; Pedrosa, R. From marine origin to therapeutics: The antitumor potential of marine algae-derived compounds. Front. Pharmacol. 2018, 9, 777. [CrossRef] [PubMed]

30. Liby, K.T.; Yore, M.M.; Sporn, M.B. Triterpenoids and rexinoids as multifunctional agents for the prevention and treatment of cancer. Nat. Rev. Cancer 2007, 7, 357-369. [CrossRef] [PubMed] 
31. Rabi, T.; Bishayee, A. Terpenoids and breast cancer chemoprevention. Breast Cancer Res. Treat. 2009, 115, 223-239. [CrossRef] [PubMed]

32. Ayyad, S.-E.N.; Abdel-Halim, O.B.; Shier, W.T.; Hoye, T.R. Cytotoxic hydroazulene diterpenes from the brown alga Cystoseira myrica. Z. Natuforsch 2003, 38, 33-38. [CrossRef]

33. Gedara, S.R.; Abdel-Halim, O.B.; El-Sharkawy, S.H.; Salama, O.M.; Shier, W.T.; Halim, A.F. Cytotoxic hydroazulene diterpenes from the brown alga Dictyota dichotoma. Z. Naturforsch 2003, 58, 17-22. [CrossRef]

34. Gouveia, V.L.M.; Seca, A.M.L.; Barreto, M.C.; Neto, A.I.; Kijjoa, A.; Silva, A.M.S. Cytotoxic meroterpenoids from the macroalga Cystoseira abies-marina. Phytochem. Lett. 2013, 6, 593-597. [CrossRef]

35. Bouaïcha, N.; Tringali, C.; Pesando, D.; Malléa, M.; Roussakis, C.; Verbist, J.F. Bioactive diterpenoids isolated from Dipophus ligulatus. Planta Med. 1993, 59, 256-258. [CrossRef] [PubMed]

36. Dorta, E.; Cueto, M.; Brito, I.; Darias, J. New terpenoids from the brown alga Stypopodium zonale. J. Nat. Prod. 2002, 65, 1727-1730. [CrossRef] [PubMed]

37. Sabry, O.M.M.; Andrews, S.; McPhail, K.L.; Goeger, D.E.; Yokochi, A.; LePage, K.T.; Murray, T.F.; Gerwick, W.H. Neurotoxic meroditerpenoids from the tropical marine brown alga Stypopodium flabelliforme. J. Nat. Prod. 2005, 68, 1022-1030. [CrossRef] [PubMed]

38. Abatis, D.; Vagias, C.; Galanakis, D.; Norris, J.N.; Moreau, D.; Roussakis, C.; Roussis, V. Atomarianones A and B: Two cytotoxic meroditerpenes from the brown alga Taonia atomaria. Tetrahedron. Lett. 2005, 46, 8525-8529. [CrossRef]

39. Pereira, D.M.; Cheel, J.; Areche, C.; San-Martin, A.; Rovirosa, J.; Silva, L.R.; Valentao, P.; Andrade, P.B. Anti-proliferative activity of meroditerpenoids isolated from the brown alga Stypopodium flabelliforme against several cancer cell lines. Mar. Drugs 2011, 9, 852-862. [CrossRef] [PubMed]

40. Reddy, P.; Urban, S. Meroditerpenoids from the southern Australian marine brown alga Sargassum fallax. Phytochemistry 2009, 70, 250-255. [CrossRef] [PubMed]

41. Kim, M.C.; Kwon, H.C.; Kim, S.N.; Kim, H.S.; Um, B.H. Plastoquinones from Sargassum yezoense; Chemical structure and effects on the activation of peroxisome proliferator-activated receptor gamma. Chem. Pharm. Bull. 2011, 59, 834-838. [CrossRef] [PubMed]

42. Sun, J.; Shi, D.; Ma, M.; Li, S.; Wang, S.; Han, L.; Yang, Y.; Fan, X.; Shi, J.; He, L. Sesquiterpenes from the red alga Laurencia tristicha. J. Nat. Prod. 2005, 68, 915-919. [CrossRef] [PubMed]

43. Shizuri, Y.; Yamada, K. Laurebiphenyl, a dimeric sesquiterpene of the cyclolaurane-type from the red Laurencia nidifica. Phytochemistry 1985, 24, 1385-1386. [CrossRef]

44. Sun, J.; Shi, D.-Y.; Wang, S.-J.; Han, L.-J.; Fan, X.; Yang, Y.-C.; Shi, J.-G. Chemical constituents of the red alga Laurencia tristicha. J. Asian Nat. Prod. Res. 2007, 9, 725-734. [CrossRef] [PubMed]

45. Zaleta-Pinet, D.A.; Holland, I.P.; Muñoz-Ochoa, M.; Murillo-Alvarez, J.I.; Sakoff, J.A.; van Altena, I.A.; McCluskey, A. Cytotoxic compounds from Laurencia pacifica. Org. Med. Chem. Lett. 2014, 4, 8. [CrossRef] [PubMed]

46. Suzuki, M.; Kurosawa, E. New aromatic sesquiterpenoids from the red alga Laurencia okamurai Yamada. Tetrahedron. Lett. 1978, 19, 2503-2506. [CrossRef]

47. Antunes, E.M.; Afolayan, A.F.; Chiwakata, M.T.; Fakee, J.; Knott, M.G.; Whibley, C.E.; Hendricks, D.T.; Bolton, J.J.; Beukes, D.R. Identification and in vitro anti-esophageal cancer activity of a series of halogenated monoterpenes isolated from the South African seaweeds Plocamium suhrii and Plocamium cornutum. Phytochemistry 2011, 72, 769-772. [CrossRef] [PubMed]

48. Sabry, O.M.M.; Goeger, D.E.; Valeriote, F.A.; Gerwick, W.H. Cytotoxic halogenated monoterpenes from Plocamium cartilagineum. Nat. Prod. Res. 2017, 31, 261-267. [CrossRef] [PubMed]

49. Mynderse, J.S.; Faulkner, D.J. Polyhalogenated monoterpenes from the red alga Plocamium cartilagineum. Tetrahedron. 1975, 31, 1963-1967. [CrossRef]

50. Crews, P. Monoterpene halogenation by the red alga Plocamium oregonum. J. Org. Chem. 1977, 42, $2634-2636$. [CrossRef] [PubMed]

51. Knott, M.G. The Natural Product Chemistry of South African Plocamium Species. Master's Thesis, Rhodes University, Grahamstown, South Africa, 2013.

52. Vogel, C.V.; Pietraszkiewicz, H.; Sabry, O.M.; Gerwick, W.H.; Valeriote, F.A.; Vanderwal, C.D. Enantioselective divergent syntheses of several polyhalogenated Plocamium monoterpenes and evaluation of their selectivity for solid tumors. Angew. Chem. 2014, 126, 12401-12405. [CrossRef] 
53. Fuller, R.W.; Cardellina, J.H., II; Kato, Y.; Brinen, L.S.; Clardy, J.; Snader, K.M.; Boyd, M.R. A pentahalogenated monoterpene from the red alga Portieria hornemannii produces a novel cytotoxicity profile against a diverse panel of human tumor cell line. J. Med. Chem. 1992, 35, 3007-3011. [CrossRef] [PubMed]

54. Kladi, M.; Xenaki, H.; Vagias, C.; Papazafiri, P.; Roussis, V. New cytotoxic sesquiterpenes from the red algae Laurencia obtuse and Laurencia microcladia. Tetrahedron. 2006, 62, 182-189. [CrossRef]

55. Kim, M.-M.; Mendis, E.; Kim, S.-K. Laurencia okamurai extract containing laurinterol induces apoptosis in melanoma cells. J. Med. Chem. 2008, 11, 260-266. [CrossRef] [PubMed]

56. Oliveira, L.S.; Tschoeke, D.A.; Oliveira, A.S.; Hill, L.J.; Paradas, W.C.; Salgado, L.T.; Thompson, C.C.; Pereira, R.C.; Thompson, F.L. New insights on the terpenone of the red seaweed Laurencia dendroidea (Florideophyceae, Rhodophyra). Mar. Drugs 2015, 13, 879-902. [CrossRef] [PubMed]

57. Fuller, R.W.; Cardellina, J.H., II; Jurek, J.; Scheuer, P.; Alvarado-Lindner, B.; McGuire, M.; Gray, G.N.; Steiner, J.R.; Clardy, J.; Menez, E.; et al. Isolation and structure/activity features of halomon-related antitumor monoterpenes from the red alga Portieria hornemannii. J. Med. Chem. 1994, 37, 4407-4411. [CrossRef] [PubMed]

58. Andrianasolo, E.H.; France, D.; Cornell-Kennon, S.; Gerwick, W.H. DNA methyl transferase inhibiting halogenated monoterpenes from the Madagascar red marine alga Portieria hornemannii. J. Nat. Prod. 2006, 69, 576-579. [CrossRef] [PubMed]

59. Schlama, T.; Baati, R.; Gouverneur, V.; Valleix, A.; Falck, J.R.; Mioskowski, C. Total synthesis of $( \pm)$-halomon by a Johnson-Claisen rearrangement. Angew. Chem. Int. Ed. 1998, 37, 2085-2087. [CrossRef]

60. Sotokawa, T.; Noda, T.; Pi, S.; Hirama, M. A three-step synthesis of halomon. Angew. Chem. Int. Ed. 2000, 39, 3430-3432. [CrossRef]

61. Bucher, C.; Deans, R.M.; Burns, N.Z. Highly selective synthesis of halomon, plocamenone and isoplocamenone. J. Am. Chem. Soc. 2015, 137, 12784-12787. [CrossRef] [PubMed]

62. Landry, M.L.; Burns, N.Z. Catalytic enantioselective dehalogenation in total synthesis. Acc. Chem. Res. 2018, 51, 1260-1271. [CrossRef] [PubMed]

63. Depix, M.S.; Martínez, J.; Santibañez, F.; Rovirosa, J.; Martín, A.S.; Maccioni, R.B. The compound 14-keto-stypodiol diacetate from the algae Stypopodium flabelliforme inhibits microtubules and cell proliferation in DU-145 human prostatic cells. Mol. Cell. Biochem. 1998, 187, 191-199. [CrossRef] [PubMed]

64. Forth, S.; Kapoor, T.M. The mechanics of microtubule networks in cell division. J. Cell Biol. 2017, 216, 1525-1531. [CrossRef] [PubMed]

65. Santibañez, J.F.; Maccioni, R.B.; Martinez, J. The secretion of urokinase-like plasminogen activator is inhibited by microtubule-interacting drugs. Cell Biochem. Funct. 1995, 13, 217-225. [CrossRef] [PubMed]

66. Parker, A.L.; Kavallaris, M.; McCarroll, J.A. Microtubules and their role in cellular stress in cancer. Front. Oncol. 2014, 4, 153. [CrossRef] [PubMed]

67. Vairappan, C.S.; Suzuki, M.; Abe, T.; Masuda, M. Halogenated metabolites with antibacterial activity from the Okinawan Laurencia species. Phytochemistry 2001, 58, 517-523. [CrossRef]

68. Suzuki, M.; Kurosawa, E.; Irie, T. Three new sesquiterpenoids containing bromine, minor constituents of Laurencia glandulifera Kützing. Tetrahedron. Lett. 1974, 15, 821-824. [CrossRef]

69. Fedorov, S.N.; Shubina, L.K.; Bode, A.M.; Stonik, V.A.; Dong, Z. Dactylone inhibits epidermal growth factor-induced transformation and phenotype expression of human cancer cells and induces G1-S arrest and apoptosis. Cancer Res. 2007, 67, 5914-5921. [CrossRef] [PubMed]

70. Tarhouni-Jabberi, S.; Zakraoui, O.; Ioannou, E.; Riach-Chebbi, I.; Haoues, M.; Roussis, V.; Kharrat, R.; Essafi-Benkhadir, K. Mertensene, a halogenated monoterpene, induces G2/M cell cycle arrest and caspase dependent apoptosis of human colon adenocarcinoma HT29 cell line through the modulation of ERK-1/-2, AKT and $\mathrm{NF}_{-\mathrm{K}} \mathrm{B}$ signalling. Mar. Drugs. 2017, 15, 221. [CrossRef] [PubMed]

71. Das, S.K.; Hashimoto, T.; Shimizu, K.; Yoshida, T.; Sakai, T.; Sowa, Y.; Komoto, A.; Kanazawa, K. Fucoxanthin induces cell cycle arrest at G0/G1 phase in human colon carcinoma cells through up-regulation of p21WAF1/Cip1. Biochim. Biophys. Acta 2005, 1726, 328-335. [CrossRef] [PubMed]

72. D'Orazio, N.; Gemello, E.; Gammone, M.A.; Girolamo, M.; Ficoneri, C.; Riccioni, G. Fucoxanthin: A treasure from the sea. Mar. Drugs 2012, 10, 604-616. [CrossRef] [PubMed]

73. Mikami, K.; Hosokawa, M. Biosynthetic pathway and health benefits of fucoxanthin, an algae-specific xanthophyll in brown seaweeds. Int. J. Mol. Sci. 2013, 14, 13763-13781. [CrossRef] [PubMed] 
74. Mori, K.; Ooi, T.; Hiraoka, M.; Oka, N.; Hamada, H.; Tamura, M.; Kusumi, T. Fucoxanthin and its metabolites in edible brown algae cultivated in deep seawater. Mar. Drugs 2004, 2, 63-72. [CrossRef]

75. Wang, S.; Li, Y.; White, W.; Lu, J. Extracts from New Zealand Undaria pinnatifida containing fucoxanthin as potential functional biomaterials against cancer in vitro. J. Funct. Biomater. 2014, 5, 29-42. [CrossRef] [PubMed]

76. Das, S.K.; Ren, R.; Hashimoto, T.; Kanazawa, K. Fucoxanthin induces apoptosis in osteoclast-like cells differentiated from RAW264.7 cells. J. Agric. Food Chem. 2010, 58, 6090-6095. [CrossRef] [PubMed]

77. Peng, J.; Yuan, J.-P.; Wu, C.-F.; Wang, J.-H. Fucoxanthin, a marine carotenoid present in brown seaweeds and diatoms: Metabolism and bioactivities relevant to human health. Mar. Drugs 2011, 9, 1806-1828. [CrossRef] [PubMed]

78. Gammone, M.A.; D'Orazio, N. Anti-obesity activity of the marine carotenoid fucoxanthin. Mar. Drugs 2015, 13, 2196-214. [CrossRef] [PubMed]

79. Zhang, H.; Tang, Y.; Zhang, Y.; Zhang, S.; Qu, J.; Wang, X.; Kong, R.; Han, C.; Liu, Z. Fucoxanthin: A promising medicinal and nutritional ingredient. Evid. Based Complement. Alternat. Med. 2015, 2015, 1-10. [CrossRef] [PubMed]

80. Kumar, S.R.; Hosokawa, M.; Miyashita, K. Fucoxanthin: A marine carotenoid exerting anti-cancer effects by affecting multiple mechanisms. Mar. Drugs 2013, 11, 5130-5147. [CrossRef] [PubMed]

81. Zorofchian Moghadamtousi, S.; Karimian, H.; Khanabdali, R.; Razavi, M.; Firoozinia, M.; Zandi, K.; Abdul Kadir, H. Anticancer and antitumor potential of fucoidan and fucoxanthin, two main metabolites isolated from brown algae. Sci. World J. 2014, 2014, 1-10. [CrossRef] [PubMed]

82. Martin, L.J. Fucoxanthin and its metabolite fucoxanthinol in cancer prevention and treatment. Mar. Drugs, 2015, 13, 4784-4798. [CrossRef] [PubMed]

83. Satomi, Y. Antitumor and cancer-preventative function of fucoxanthin: A marine carotenoid. Anticancer Res. 2017, 37, 1557-1562. [CrossRef] [PubMed]

84. Okuzumi, J.; Nishino, H.; Murakoshi, M.; Iwashima, A.; Tanaka, Y.; Yamane, T.; Fujita, Y.; Takahashi, T. Inhibitory effects of fucoxanthin, a natural carotenoid, on $\mathrm{N}$-myc expression and cell cycle progression in human malignant tumor cells. Cancer Lett. 1990, 55, 75-81. [CrossRef]

85. Hosokawa, M.; Wanezaki, S.; Miyauchi, K.; Kurihara, H.; Kohno, H.; Kawabata, J.; Odashima, S.; Takahashi, K. Apostosis-inducing effect of fucoxanthin on human leukemia cell line HL-60. Food Sci. Technol. Res. 1999, 5, 243-246. [CrossRef]

86. Kotake-Nara, E.; Kushiro, M.; Zhang, H.; Sugawara, T.; Miyashita, K.; Nagao, A. Carotenoids affect proliferation of human prostate cancer cells. J. Nutr. 2001, 131, 3303-3306. [CrossRef] [PubMed]

87. Kotake-Nara, E.; Asai, A.; Nagao, A. Neoxanthin and fucoxanthin induce apoptosis in PC3 human prostate cancer cells. Cancer Lett. 2005, 220, 75-84. [CrossRef] [PubMed]

88. Hosokawa, M.; Kudo, M.; Maeda, H.; Kohno, H.; Tanaka, T.; Miyashita, K. Fucoxanthin induces apoptosis and enhances the antiproliferative effect of the PPAR $\gamma$ ligand, troglitazone, on colon cancer cells. Biochim. Biophys. Acta 2004, 1675, 113-119. [CrossRef] [PubMed]

89. Satomi, Y.; Nishino, H. Implication of mitogen-activated protein kinase in the induction of G1 cell cycle arrest and gadd45 expression by the carotenoid fucoxanthin in human cancer cells. Biochim. Biophys. Acta 2009, 1790, 260-266. [CrossRef] [PubMed]

90. Das, S.K.; Hashimoto, T.; Kanazawa, K. Growth inhibition of human hepatic carcinoma HepG2 cells by fucoxanthin is associated with down-regulation of cyclin D. Biochim. Biophys. Acta 2008, 1780, 743-749. [CrossRef] [PubMed]

91. Zhang, Z.Y.; Zhang, P.J.; Hamada, M.; Takahashi, S.; Xing, G.Q.; Liu, J.Q.; Sugiura, N. Potential chemoprevention effect of dietary fucoxanthin on urinary bladder cancer EJ-1 cell line. Oncol. Rep. 2008, 20, 1099-1110. [CrossRef] [PubMed]

92. Liu, C.L.; Huang, Y.S.; Hosokawa, M.; Miyashita, K.; Hu, M.L. Inhibition of proliferation of a hepatoma cell line by fucoxanthin in relation to cell cycle arrest and enhanced gap junctional intercellular communication. Chem. Biol. Interact. 2009, 182, 165-172. [CrossRef] [PubMed]

93. Kim, K.-N.; Heo, S.-J.; Kang, S.-M.; Ahn, G.; Jeon, Y.-J. Fucoxanthin induces apoptosis in human leukemia HL-60 cells through a ROS-mediated Bcl-xL pathway. Toxicol. In Vitro 2010, 24, 1648-1654. [CrossRef] [PubMed] 
94. Yu, R.X.; Hu, X.M.; Xu, S.Q.; Jiang, Z.J.; Yang, W. Effects of fucoxanthin on proliferation and apoptosis in human gastric adenocarcinoma MGC-803 cells via JAK/STAT signal pathway. Eur. J. Pharmacol. 2011, 657, 10-19. [CrossRef] [PubMed]

95. Satomi, Y. Fucoxanthin induces GADD45A expression and G1 arrest with SAPK/JNK activation in LNCap Human prostate cancer cells. Anticancer Res. 2012, 32, 807-814. [PubMed]

96. Ganesan, P.; Matsubara, K.; Sugawara, T.; Hirata, T. Marine algal carotenoids inhibit angiogenesis by down-regulating FGF-2-mediated intracellular signals in vascular endothelial cells. Mol. Cell. Biochem. 2013, 380, 1-9. [CrossRef] [PubMed]

97. Wang, L.; Zeng, Y.; Liu, Y.; Hu, X.; Li, S.; Wang, Y.; Li, L.; Lei, Z.; Zhang, Z. Fucoxanthin induces growth arrest and apoptosis in human bladder cancer T24 cells by up-regulation of p21 and down-regulation of mortalin. Acta Biochim. Biophys. Sin. 2014, 46, 877-884. [CrossRef] [PubMed]

98. Liu, Y.; Zheng, J.; Zhang, Y.; Wang, Z.; Yang, Y.; Bai, M.; Dai, Y. Fucoxanthin activates apoptosis via inhibition of PI3K/Akt/mTOR pathway and supresses invasion and migration by restriction of p38-MMP-2/9 in human glioblastoma cells. Neurochem. Res. 2016, 41, 2728-2751. [CrossRef] [PubMed]

99. Jin, Y.; Qiu, S.; Shao, N.; Zheng, J. Fucoxanthin and tumour necrosis factor-related apoptosis-inducing ligand (TRAIL) synergistically promotes apoptosis of human cervical cancer cells by targeting PI3K/Akt/NF-B signalling pathway. Med. Sci. Monit. 2018, 24, 11-18. [CrossRef] [PubMed]

100. Zhu, Y.; Cheng, J.; Min, Z.; Yin, T.; Zhang, R.; Zhang, W.; Hu, L.; Cui, Z.; Gao, C.; Xu, S.; et al. Effect of fucoxanthin on autophagy and apoptosis in SGC-7901 cells and the mechanism. J. Cell Biochem. 2018, 119, 7274-7284. [CrossRef] [PubMed]

101. Beppu, F.; Niwano, Y.; Tsukui, T.; Hosokawa, M.; Miyashita, K. Single and repeated oral dose toxicity study of fucoxanthin (FX), a marine carotenoid, in mice. J. Toxicol. Sci. 2009, 34, 501-510. [CrossRef] [PubMed]

102. Almeida, T.P.; Ferreira, J.; Vettorazzi, A.; Azqueta, A.; Rocha, E.; Ramos, A.A. Cytotoxic activity of fucoxanthin, alone and in combination with the cancer drugs imatinib and doxorubicin, in CML cell lines. Environ. Toxicol. Pharmacol. 2018, 59, 24-33. [CrossRef] [PubMed]

103. Huang, Z.; Xu, L.; Zhu, X.; Hu, J.; Peng, H.; Zeng, Z.; Xiong, H. Stability and bioaccessibility of fucoxanthin in nanoemulsions prepared from pinolenic acid-contained structured lipid. Int. J. Food Eng. 2017, 13, 1-14. [CrossRef]

104. Vo, D.T.; Saravana, P.S.; Woo, H.-C.; Chun, B.-S. Fucoxanthin-rich oil encapsulation using biodegradable polyethylene glycol and particles from gas-saturated solutions technique. J. CO2 Util. 2018, 26, 359-369. [CrossRef]

105. Li, H.; Xu, Y.; Sun, X.; Wang, S.; Wang, J.; Zhu, J.; Wang, D.; Zhao, L. Stability, bioactivity, and bioaccessibility of fucoxanthin in zein-caseinate composite nanoparticles fabricated at neutral $\mathrm{pH}$ by antisolvent precipitation. Food Hydrocol. 2018, 84, 379-388. [CrossRef]

106. Ravi, H.; Kurrey, N.; Manabe, Y.; Sugawara, T.; Baskaran, V. Polymeric chitosan-glycolipid nanocarriers for an effective delivery of marine carotenoid fucoxanthin for induction of apoptosis in human colon Check for cancer cells (Caco-2 cells). Mater. Sci. Eng. C Mater. Biol. Appl. 2018, 91, 785-795. [CrossRef] [PubMed]

107. Sugawara, T.; Baskaran, V.; Tsuzuki, W.; Nagao, A. Brown algae fucoxanthin is hydrolysed to fucoxanthinol during absorption by CaCo-2 human intestinal cells and mice. J. Nutr. 2002, 132, 946-951. [CrossRef] [PubMed]

108. Konishi, I.; Hosokawa, M.; Sashima, T.; Kobayashi, H.; Miyashita, K. Halocynthiaxanthin and fucoxanthinol isolated from Halocynthia roretzi induce apoptosis in human leukemia, breast and colon cancer cells. Comp. Biochem. Physiol. C 2006, 142, 53-59. [CrossRef] [PubMed]

109. Rwigemera, A.; Mamelona, J.; Martin, L.J. Inhibitory effects of fucoxanthinol on the viability of human breast cancer cell lines MCF-7 and MDA-MB-231 are correlated with modulation of the NF-kB pathway. Cell Biol. Toxicol. 2014, 30, 157-167. [CrossRef] [PubMed]

110. Asai, A.; Sugawara, T.; Ono, H.; Nagao, A. Biotransformation of fucoxanthinol into amarouciaxanthin A in mice and HepG2 cells: Formation and cytotoxicity of fucoxanthin metabolites. Drug Metab. Dispos. 2004, 32, 205-211. [CrossRef] [PubMed]

111. Ishikawa, C.; Tafuku, S.; Kadekaru, T.; Sawada, S.; Tomita, M.; Okudaira, T.; Nakazato, T.; Toda, T.; Uchihara, J.-N.; Taira, N.; et al. Antiadult T-cell leukemia effects of brown algae fucoxanthin and its deacetylated product, fucoxanthinol. Int. J. Cancer 2008, 123, 2702-2712. [CrossRef] [PubMed] 
112. Yamamoto, K.; Ishikawa, C.; Katano, H.; Yasumoto, T.; Mori, N. Fucoxanthin and its deacetylated product, fucoxanthinol, induce apoptosis of primary effusion lymphomas. Cancer Lett. 2011, 300, 225-234. [CrossRef] [PubMed]

113. Li, Y.-X.; Wijesekara, I.; Li, Y.; Kim, S.-K. Phlorotannins as bioactive agents from brown algae. Process Biochem. 2011, 46, 2219-2224. [CrossRef]

114. Gómez-Guzmán, M.; Rodríguez-Nogales, A.; Algieri, F.; Gálvez, J. Potential role of seaweed polyphenols in cardiovascular-associated disorders. Mar. Drugs 2018, 16, 250. [CrossRef]

115. Gutiérrez-Rodríguez, A.G.; Juárez-Portilla, C.; Olivares-Bañuelos, T.; Zepeda, R.C. Anticancer activity of seaweeds. Drug Discov. Today 2018, 23, 434-447. [CrossRef] [PubMed]

116. Cabrita, M.T.; Vale, C.; Rauter, A.P. Halogenated compounds from marine algae. Mar. Drugs 2010, 8, 2301-2317. [CrossRef] [PubMed]

117. Catarino, M.D.; Silva, A.M.S.; Cardoso, S.M. Fucaceae: A source of bioactive phlorotannins. Int. J. Mol. Sci. 2017, 18, 1327. [CrossRef]

118. Tanniou, A.; Vandanjon, L.; Incera, M.; Serrano, L.E.; Husa, V.; Grand, J.; Nicolas, J.L.; Poupart, N.; Kervarec, N.; Engelen, A.; et al. Assessment of the spatial variability of phenolic contents and associated bioactivities in the invasive alga Sargassum muticum sampled along its European range from Norway to Portugal. J. Appl. Phycol. 2013, 26, 1215-1230. [CrossRef]

119. Abdala-Díaz, R.; Cabello-Pasini, A.; Pérez-Rodríguez, E.; Álvarez, R.; Figueroa, F. Daily and seasonal variations of optimum quantum yield and phenolic compounds in Cystoseira tamariscifolia (Phaeophyta). Mar. Biol. 2006, 148, 459-465. [CrossRef]

120. Yoshie, Y.; Wang, W.; Petillo, D.; Suzuki, T. Distribution of catechins in Japanese seaweeds. Fish Sci. 2000, 66, 998-1000. [CrossRef]

121. Rodríguez-Bernaldo de Quirós, A.; Lage-Yusty, M.A.; López-Hernández, J. Determination of phenolic compounds in macroalgae for human consumption. Food Chem. 2010, 121, 634-638. [CrossRef]

122. Lopes, G.; Andrade, P.B.; Valentão, P. Phlorotannins: Towards new pharmacological interventions for diabetes mellitus type 2. Molecules 2017, 22, 56. [CrossRef] [PubMed]

123. Glombitza, K.-W.; Pauli, K. Fucols and phlorethols from the brown alga Scytothamnus australis hook. et harv. (Chnoosporaceae). Bot. Mar. 2003, 46, 315-320. [CrossRef]

124. Singh, I.P.; Bharate, S.B. Phloroglucinol compounds of natural origin. Nat. Prod. Rep. 2006, 23, 558-591. [CrossRef] [PubMed]

125. Hussain, S.P.; Hofseth, L.J.; Harris, C.C. Radical causes of cancer. Nat. Rev. Cancer 2003, 3, 276-285. [CrossRef] [PubMed]

126. Wijesekara, I.; Yoon, N.Y.; Li, Y.; Kim, S.-K. Phlorotannins from Ecklonia cava (Phaeophyceae): Biological activities and potential health benefits. BioFactors 2010, 36, 408-414. [CrossRef] [PubMed]

127. Kong, C.-S.; Kim, J.-A.; Yoon, N.-Y.; Kim, S.-K. Induction of apoptosis by phloroglucinol derivative from Ecklonia Cava in MCF-7 human breast cancer cells. Food Chem. Toxicol. 2009, 47, 1653-1658. [CrossRef] [PubMed]

128. Kim, A.-R.; Shin, T.-S.; Lee, M.S.; Park, J.-Y.; Park, K.-E.; Yoon, N.-Y.; Kim, J.-S.; Choi, J.-S.; Jang, B.-C.; Byun, D.-S.; et al. Isolation and identification of phlorotannins from Ecklonia stolonifera with antioxidant and anti-inflammatory properties. J. Agric. Food Chem. 2009, 57, 3483-3489. [CrossRef] [PubMed]

129. Ryu, B.; Ahn, B.N.; Kang, K.H.; Kim, Y.S.; Li, Y.X.; Kong, C.S.; Kim, S.K.; Kim, D.G. Dioxinodehydroeckol protects human keratinocyte cells from UVB-induced apoptosis modulated by related genes Bax/Bcl-2 and caspase pathway. J. Photochem. Photobiol. B 2015, 153, 352-357. [CrossRef] [PubMed]

130. Kim, E.-K.; Tang, Y.; Kim, Y.-S.; Hwang, J.-W.; Choi, E.-J.; Lee, J.-H.; Lee, S.-H.; Jeon, Y.-J.; Park, P.-J. First evidence that Ecklonia cava-derived dieckol attenuated MCF-7 human breast carcinoma cell migration. Mar. Drugs 2015, 13, 1785-1797. [CrossRef] [PubMed]

131. Ahn, J.-H.; Yang, Y.-I.; Lee, K.-T.; Choi, J.-H. Dieckol, isolated from the edible brown algae Ecklonia cava induces apoptosis of ovarian cancer cells and inhibits tumour xenograft growth. J. Cancer Res. Clin. Oncol. 2015, 141, 255-268. [CrossRef] [PubMed]

132. Kim, R.-K.; Uddin, N.; Hyun, J.-W.; Kim, C.; Suh, Y.; Lee, S.-J. Novel anticancer activity of phloroglucinol against breast cancer stem-like cells. Toxicol. Appl. Pharm. 2015, 286, 143-150. [CrossRef] [PubMed] 
133. Kim, R.-K.; Suh, Y.; Yoo, K.C.; Cui, Y.-H.; Hwang, E.; Kim, H.-J.; Kang, J.-S.; Kim, M.-J.; Lee, Y.Y.; Lee, S.-J. Phloroglucinol suppresses metastatic ability of breast cancer cells by inhibition of epithelial-mesenchymal cell transition. Cancer Sci. 2015, 106, 94-101. [CrossRef] [PubMed]

134. Katsui, N.; Suzuki, Y.; Kitamura, S.; Irie, T. 5,6-dibromoprotocatechualdehyde and 2,3-dibromo-4,5-dihydroxybenzyl methyl ether: New dibromophenols from Rhodomela larix. Tetrahedron 1967, 23, 1185-1188. [CrossRef]

135. Kurata, K.; Taniguchii, K.; Takashima, K.; Hayashi, I.; Suzuki, M. Feeding-deterrent bromophenols from Odonthalia corymbifera. Phytochemistry 1997, 45, 485-487. [CrossRef]

136. Kurihara, H.; Mitani, T.; Kawabata, J.; Takahashi, K. Two new bromophenols from the red alga Odonthalia corymbifera. J. Nat. Prod. 1999, 62, 882-884. [CrossRef] [PubMed]

137. Shoeib, N.A.; Bibby, M.C.; Blunden, G.; Linley, P.A.; Swaine, D.J.; Wheelhouse, R.T.; Wright, C.W. In-vitro cytotoxic activities of the major bromophenols of the red alga Polysiphonia lanosa and some novel synthetic isomers. J. Nat. Prod. 2004, 67, 1445-1449. [CrossRef] [PubMed]

138. Barreto, M.; Meyer, J.J.M. Isolation and antimicrobial activity of a lanosol derivative from Osmundaria serrata (Rhodophyta) and a visual exploration of its biofilm covering. S. Afr. J. Bot. 2006, 72, 521-528. [CrossRef]

139. Liu, M.; Hansen, P.E.; Lin, X. Bromophenols in marine algae and their bioactivities. Mar. Drugs 2011, 9, 1273-1292. [CrossRef] [PubMed]

140. Weinstein, B.; Rold, T.L.; Harrell, C.E.; Burns, M.W., III; Waaland, J.R. Re-examination of the bromophenols in the red alga Rhodomela Larix. Phytochemistry 1975, 14, 2667-2670. [CrossRef]

141. Han, L.; Xu, N.; Shi, J.; Yan, X.; Zheng, C. Isolation and pharmacological activities of bromophenols from Rhodomela confervoides. Chin. J. Oceanol. Limn. 2005, 23, 226-229. [CrossRef]

142. Xu, X.-L.; Fan, X.; Sing, F.-H.; Zhao, J.-L.; Han, L.-J.; Yang, Y.-C.; Shi, J.-G. Bromophenols from the brown alga Leathesia nana. J. Asian Nat. Prod. Res. 2004, 6, 217-221. [CrossRef] [PubMed]

143. Dayong, S.; Jing, L.; Shuju, G.; Hua, S.; Xiao, F. The antitumor effect of bromophenol derivatives in vitro and Leathesia nana extract in vivo. Chin. J. Oceanol. Limn. 2009, 27, 277-282. [CrossRef]

144. Fan, X.; Xu, N.-J.; Shi, J.-G. Bromophenols from the red alga Rhodomela confervoides. J. Nat. Prod. 2003, 66, 455-458. [CrossRef] [PubMed]

145. Wu, N.; Luo, J.; Jiang, B.; Wang, L.; Wang, S.; Wang, C.; Fu, C.; Li, J.; Shi, D. Marine bromophenol bis (2,3-dibromo-4,5-dihydroxy-phenyl)-methane inhibits the proliferation, migration, and invasion of hepatocellular carcinoma cells via modulating 31-Integrin/FAK signaling. Mar. Drugs 2015, 13, 1010-1025. [CrossRef] [PubMed]

146. Wang, S.; Wang, L.-J.; Jiang, B.; Wu, N.; Li, X.; Liu, S.; Luo, J.; Shi, D. Anti-angiogenic properties of BDDPM, a bromophenol from marine red alga Rhodomela confervoides, with multi receptor tyrosine kinase inhibition effects. Int. J. Mol. Sci. 2015, 16, 13548-13560. [CrossRef] [PubMed]

147. Yared, M.A.; Middleton, L.P.; Meric, F.; Cristofanilli, M.; Sahin, A.A. Expression of c-kit proto-oncogene product in breast tissue. Breast J. 2004, 10, 323-327. [CrossRef] [PubMed]

148. Liu, M.; Zhang, W.; Wei, J.; Qiu, L.; Lin, X. Marine bromophenol bis(2,3-dibromo-4,5-dihydroxybenzyl) ether, induces mitochondrial apoptosis in K562 cells and inhibits topoisomerase I in vitro. Toxicol. Lett. 2012, 211, 126-134. [CrossRef] [PubMed]

149. Seiter, K. Toxicity of the topoisomerase I inhibitors. Expert Opin. Drug Saf. 2005, 4, 45-53. [CrossRef] [PubMed]

150. Qi, X.; Liu, G.; Qiu, L.; Lin, X.; Liu, M. Marine bromophenol bis(2,3-dibromo-4,5-dihydroxybenzyl) ether, represses angiogenesis in HUVEC cells and in zebrafish embryos via inhibiting the VEGF signal systems. Biomed. Pharmacother. 2015, 75, 58-66. [CrossRef] [PubMed]

151. Güven, K.C.; Percot, A.; Sezik, E. Alkaloids in marine algae. Mar. Drugs 2010, 8, 269-284. [CrossRef] [PubMed]

152. Barbosa, M.; Valentão, P.; Andrade, P.B. Bioactive compounds from macroalgae in the new Millennium: Implications for neurodegenerative diseases. Mar. Drugs 2014, 12, 4934-4972. [CrossRef] [PubMed]

153. Gross, H.; Goeger, D.E.; Hills, P.; Mooberry, S.L.; Ballantine, D.L.; Murray, T.F.; Valeriote, F.A.; Gerwick, W.H. Lophocladines, bioactive alkaloids from the red alga Lophocladia sp. J. Nat. Prod. 2006, 69, 640-644. [CrossRef] [PubMed]

154. Prasad, V.V.T.S.; Gopalan, R.O.G. Continued use of MDA-MB-435, a melanoma cell line, as a model for human breast cancer, even in year, 2014. NPJ Breast Cancer 2015, 1. [CrossRef] [PubMed] 
155. Lotter, M.; Schilling, J.; Reimann, E.; Bracher, F. First total synthesis of the 2,7-naphthyridine alkaloids lophocladine A and B. Arch. Pharm. Chem. Life Sci. 2006, 339, 677-679. [CrossRef] [PubMed]

156. Zhang, A.; Ding, C.; Cheng, C.; Yao, Q. Convenient synthesis of 2,7-naphthyridine lophocladines A and B and their analogues. J. Comb. Chem. 2007, 9, 916-919. [CrossRef] [PubMed]

157. Disadee, W.; Ploypradith, P.; Aree, T.; Chaichit, N.; Ruchirawat, S. A novel approach for the synthesis of lophocladines A, B and C1 analogues. Tetrahedron. Lett. 2011, 52, 6142-6144. [CrossRef]

158. Theeramunkong, S.; Vajragupta, O.; Mudjupa, C. Synthesis and biological evaluation of simplified analogs of lophocladine B as potential antitumor agents. Med. Chem. Res. 2016, 25, 2959-2964. [CrossRef]

159. Kochanowska-Karamyan, A.J.; Hamann, M.T. Marine indole alkaloids: Potential new drug leads for the control of depression and anxiety. Chem. Rev. 2010, 110, 4489-4497. [CrossRef] [PubMed]

160. Netz, N.; Till, O. Marine indole alkaloids. Mar. Drugs 2015, 13, 4814-4914. [CrossRef] [PubMed]

161. Lunagariya, J.; Bhadja, P.; Zhong, S.; Vekariya, R.; Xu, S. Marine natural product bis-indole alkaloid caulerpin: Chemistry and biology. MiniRev. Med. Chem. 2017. [CrossRef] [PubMed]

162. Vest, S.E.; Dawes, C.J.; Romeo, J.T. Distribution of caulerpin and caulerpicin in eight species of the green alga Caulerpa (Caulerpales). Bot. Mar. 1983, 26, 313-316. [CrossRef]

163. Anjaneyulu, A.S.R.; Prakash, C.V.S.; Mallavadhani, U.V. Sterols and terpenes of the marine green algal species Caulerpa racemosa and Codium decorticatum. J. Indian Chem. Soc. 1991, 68, 480.

164. Yan, S.; Su, J.; Wang, Y.; Zeng, L. Studies on chemical constituents of Halimeda incrassata. Trop. Ocean 1999, 18, 91-94.

165. Govenkar, M.B.; Wahidulla, S. Constituents of Chondria armata. Phytochemistry 2000, 54, 979-981. [CrossRef]

166. Xu, X.; Su, J. The separation, identification and bioassay of caulerpin. Ziran Kexueban 1996, 35, 64-66.

167. Liu, Y.; Morgan, J.B.; Coothankandaswamy, V.; Liu, R.; Jekabsons, M.B.; Mahdi, F.; Nagle, D.G.; Zhou, Y.-D. The Caulerpa pigment caulerpin inhibits HIF-1 activation and mitochondrial respiration. J. Nat. Prod. 2009, 72, 2104-2109. [CrossRef] [PubMed]

168. Yu, H.; Zhang, H.; Dong, M.; Wu, Z.; Shen, Z.; Xie, Y.; Kong, Z.; Dai, X.; Xu, B. Metabolic reprogramming and $\mathrm{AMPK} \alpha 1$ pathway activation by caulerpin in colorectal cancer cells. Int. J. Oncol. 2017, 50, 161-172. [CrossRef] [PubMed]

169. Ferramosca, A.; Conte, A.; Guerra, F.; Felline, S.; Rimoli, M.G.; Mollo, E.; Zara, V.; Terlizzi, A. Metabolites from invasive pests inhibit mitochondrial complex II: A potential strategy for the treatment of human ovarian carcinoma. Biochem. Biophys. Res. Commun. 2016, 473, 1133-1138. [CrossRef] [PubMed]

170. Montopoli, M.; Bellanda, M.; Lonardoni, F.; Ragazzi, E.; Dorigo, P.; Froldi, G.; Mammi, S.; Caparrotta, L. Metabolic reprogramming in ovarian cancer cells resistant to cisplatin. Curr. Cancer Drug Tragets 2011, 11, 226-235. [CrossRef]

171. Okuzumi, J.; Takahashi, T.; Yamane, T.; Kitao, Y.; lnagake, M.; Ohya, K.; Nishino, H.; Tanaka, Y. Inhibitory effects of fucoxanthin, a natural crotenoid, on $N$-ethyl- $N^{\prime}$-nitro- $N$-nitrosoguanidine-induced mouse duodenal carcinogenesis. Cancer Lett. 1993, 68, 159-168. [CrossRef]

172. Auvinen, M.; Laine, A.; Paasinen-Sohns, A.; Kangas, A.; Kangas, L.; Saksela, O.; Andersson, L.C.; Hölttä, E. Human ornithine decarboxylase-overproducing NIH3T3 cells induce rapidly growing, highly vascularized enphatiss in nude mice. Cancer Res. 1997, 57, 3016-3025. [PubMed]

173. Shimoda, H.; Tanaka, J.; Shan, S.-J.; Maoka, T. Anti-pigmentary activity of fucoxanthin and its influence on skin mRNA expression of melanogenic molecules. J. Pharm. Pharmacol. 2010, 62, 1137-1145. [CrossRef] [PubMed]

174. Wang, J.; Chen, S.; Xu, S.; Yu, X.; Ma, D.; Hu, X.; Cao, X. In vivo induction of apoptosis by fucoxanthin, a marine carotenoid, associated with down-regulating STAT3/EGFR signalling in Sarcoma 180 (S180) xenografts-bearing mice. Mar. Drugs 2012, 10, 2055-2068. [CrossRef] [PubMed]

175. Sadeeshkumar, V.; Duraikannu, A.; Ravichandran, S.; Kodisundaram, P.; Fredrick, W.S.; Gobalakrishnan, R. Modulatory efficacy of dieckol on xenobiotic-metabolizing enzymes, cell proliferation, apoptosis, invasion, and angiogenesis during NDEA-induced rat hepatocarcinogenesis. Mol. Cell Biochem. 2017, 433, 195-204. [CrossRef] [PubMed]

(C) 2018 by the authors. Licensee MDPI, Basel, Switzerland. This article is an open access article distributed under the terms and conditions of the Creative Commons Attribution (CC BY) license (http://creativecommons.org/licenses/by/4.0/). 